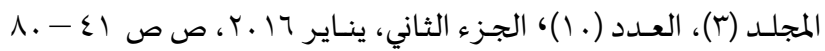

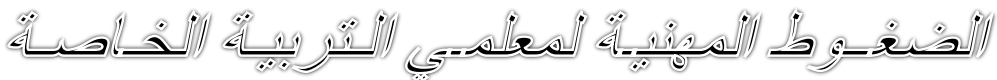

$$
\begin{aligned}
& \text { (lll) }
\end{aligned}
$$

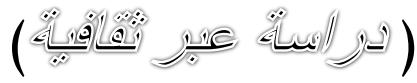

$$
\begin{aligned}
& \text { إعداد } \\
& \text { د/ علي عبد/الله علي مسافر }
\end{aligned}
$$

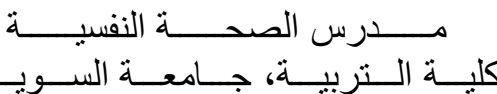$$
\text { DOI: } 10.12816 / 0021327
$$ 
الضغوط الهنية لهعلمي التربية الخاصة في ضوء بعض الهتغيرات (دراسة عبر ثقافية) إعداد

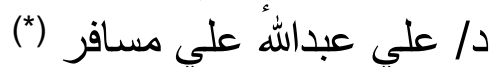

\section{DOl: 10.12816/0021327}

$$
\text { ملنص الطنوط }
$$

تهدف الدراسة الحالية إلى استقصاء الضغوط المهنية لمعلمي التربية الخاصـة في كل

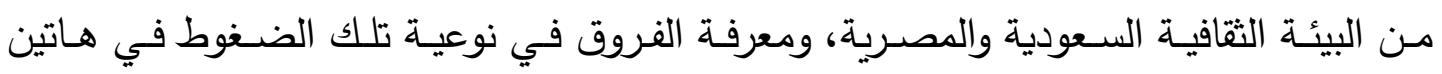

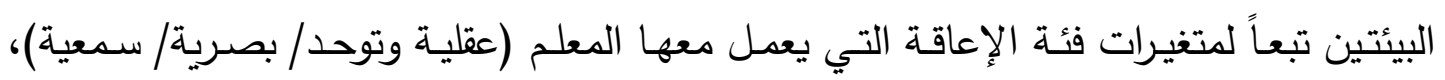

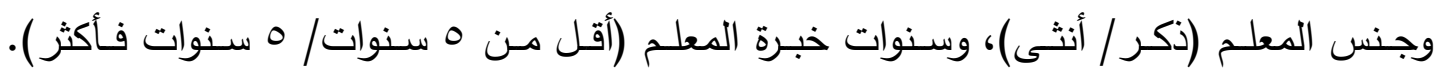

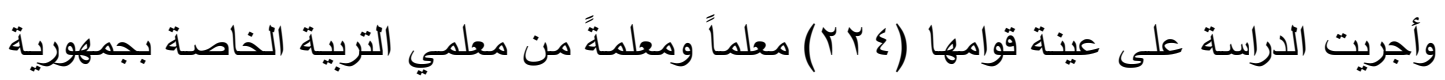

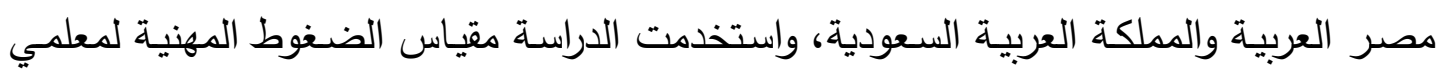
التربية الخاصة (إعداد الباحث)، ولتحليل البيانات تم تطبيق اختبار "ت"، وتحليل التباين المتعدد

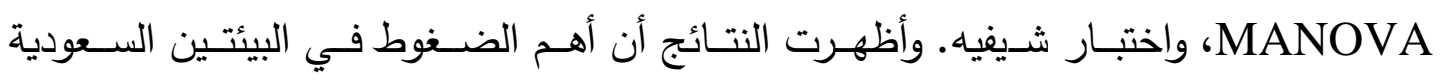

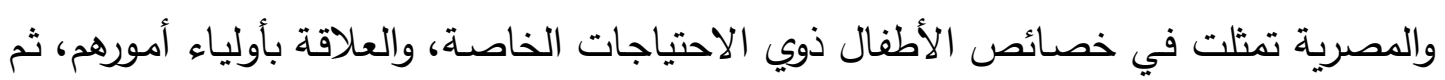

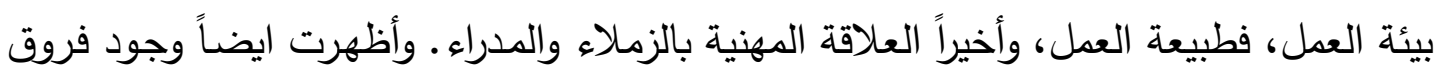

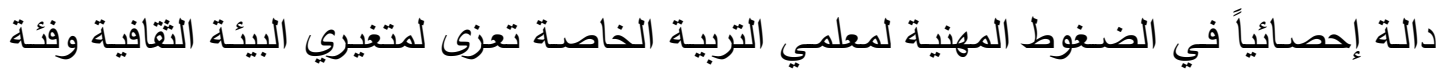

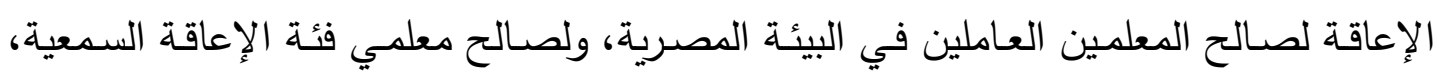

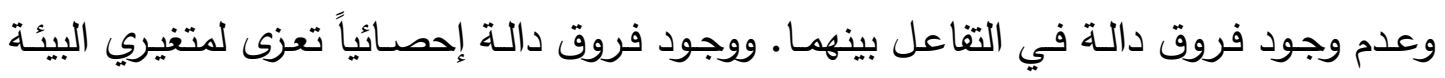

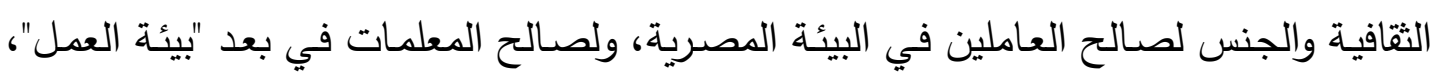
وعدم وجود فروق في التفاعل بين المتغيرين. ووجود فروق دالة إحصائياً تعزى لمتغيري البيئة

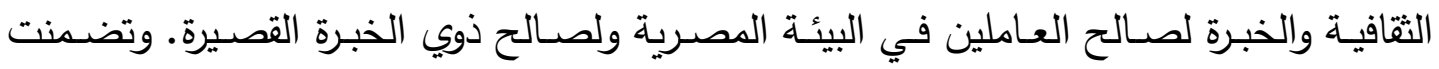

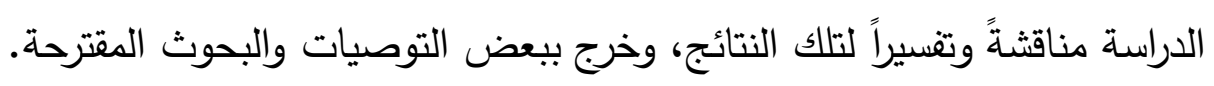

الكلمات المفتاحية: الضغوط المهنيـة/ضـغوط العمل، معلم التربيـة الخاصـة، ذوو الاحتياجات الخاصة، عبر ثثقافية. 


\section{Special Education Teachers' Professional Stress in the light of Some Variables [ A Gross-Gultural Study ] \\ Ahstract}

This study aimed at studying professional stress facing special education teachers in the Egyptian and Saudi cultural environments and its relation to some variables including category of children's disability, teacher's gender and experience. The study was applied to 224 special education teachers in Egypt and Saudi Arabia. It used the Special Education Teachers' Professional Stress Scale which was prepared by the researcher. T-test, MANOVA, Scheffe tests were used in statistical analysis of data. Results show that the most important stress in both Egyptian and Saudi environments are characteristics of children with special needs, teachers' relations with children's parents, work environment, work nature and finally the teachers' relations with their managers and colleagues. Results also show that there were statistically significant differences in professional stress attributed to the cultural environment and the category of children's disability in favour of the Egyptian environment and teachers working with children with hearing disability, but there were no statistically significant differences that can be attributed to the interaction between the two variables. There were also statistically significant differences attributed to the cultural environment and the teacher's gender in favour of teachers working in the Egyptian environment and in favour of females on the "work environment" dimension, but there no statistically significant differences that can be attributed to the interaction between the two variables. There were statistically significant differences attributed to the cultural environment and the teacher's experience in favour of the Egyptian environment and teachers with shorter experience. Results were discussed and explained. Recommendations are included.

Key words: professional/ job stress, special education teachers/ special educators, children with special needs, cross-cultural. 
الحياة مليئة بالضغوط والهموم، وقد وصف ربنا عز وجل حياة الإنسان بالكبد والعناء

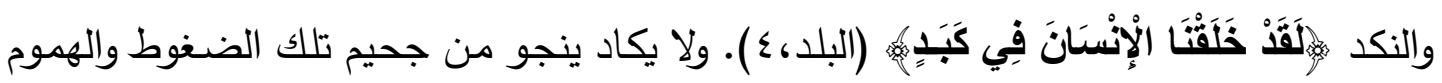

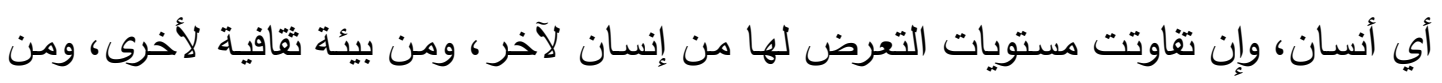

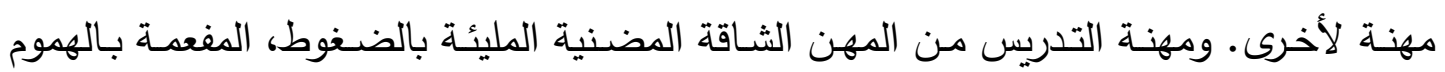

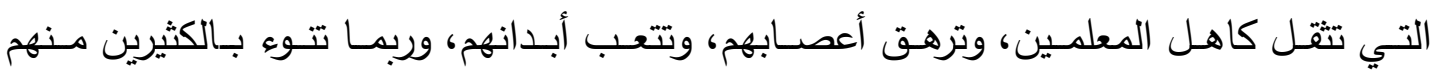

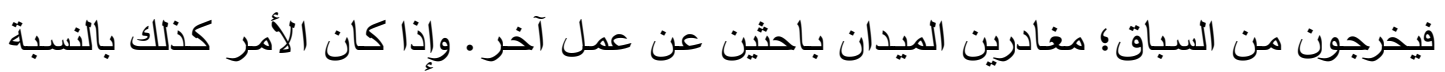

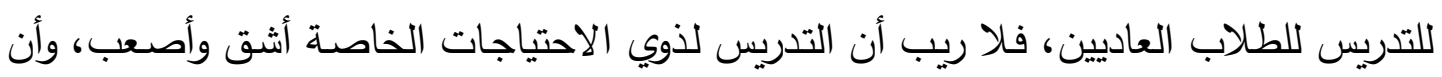
مجال تأثير الضغوط المهنية فيه أوسع وأرحب، وأن آثارها أخطر وأكبر وأكثر .

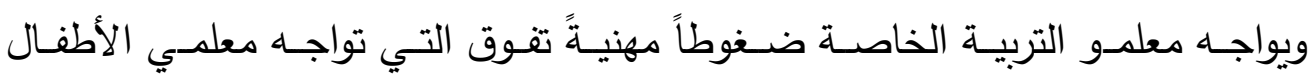

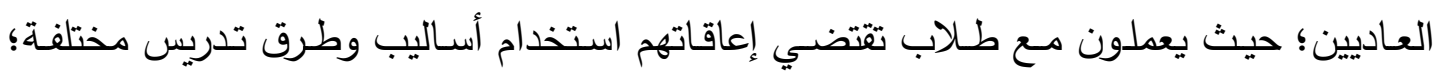
ومثلهم مثل معلمي الأطفال العاديين يقومون بإعداد خطط الدروس، والتدريس، وتقويم أداء الطلاب، إلا أن لديهم التزامات إضـافية مثل المساعدة في تشخيص الأطفال ذوي الاحتياجات

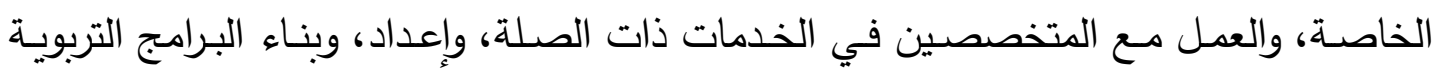
الفردية، وتوجيه وإرشاد الآباء بخصوص حالة أبنائهم. ومع تزايد الأدوار المنوطة بهم بالإضافة إلى مطالب اللوائح والقوانين والإدارات التعليمية، فليس من عجب في في أن تظل الضغنوط المهنية لديهم في تزايد وارتفاع (Green, 1994; Kodavatiganti, \& Bulusu, 2011). وتشـير كثير مـن الدراسـات إلى زيـادة انتشـار الضــوط المهنيـة بـين معلمي التربيـة

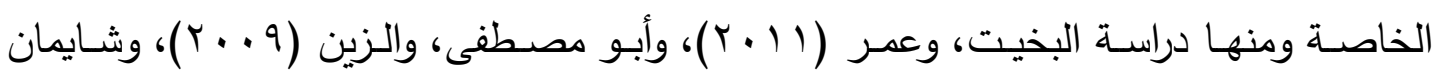
Shyman

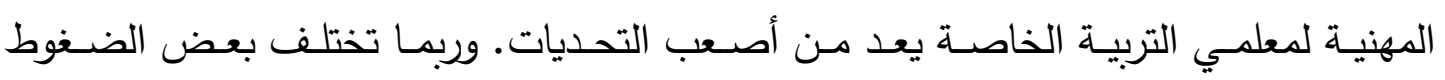

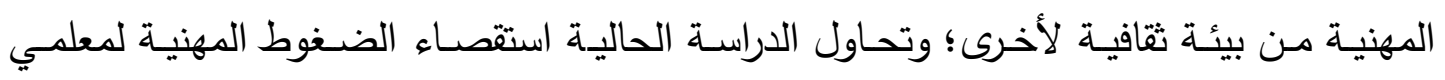
التربية الخاصة في بيئتين ثقافيتين عربيتين هما البيئة السعودية والمصرية، والكثف عن عن الفروق لهنه في هذه الضغوط فيهما في ضوء بعض المتغيرات؛ ومن ثم فهما والسعي لضبطها والحد منها. 
أثناء عمل الباحث بمهنة التدريس واجـه الكثير من المشكلات والضغوط المتعلقة بتلك المهنة. وعندما خاض الباحث غمار ميدان التربية الخاصـة، ودرس خصـائص واحتياجات ذوي الاحتياجـات الخاصـة، والضـغوط المترتبـة على الإعاقات؛ أيقن أن التدريس لتلك الفئات أشق وأصعب، وأدرك أن معلمي التربية الخاصة مثقلةُ كواهلهم بأعباء وضغوط إضافية تفوق الأعباء والضـغوط التي يتعرض لها معلو الأطفال العاديين وذوو المهن الأخرى. ومن خـلال احتكاك الباحث ببعض معلمي التربية الخاصـة في جمهوريـة مصر العربية والمملكة العربية السعودية استشرف أنه ربما توجد فروق في الضغوط المهنية التي يتعرض لها معلمو التربية الخاصـة في البيئتين، وعند اطلاعـه على بعض الدراسـات التي تتاولت الضـغوط المهنيـة لمعلمي التربيـة الخاصـة لاحظ تباينـا وتتاقضـاً في نتائج بعض الدراسـات؛ ممـا حداه لإجـراء الدراسـة الحالية لاستكثاف العلاقـة بين الضـغوط التي يتعرض لها معلمو التربية الخاصـة وبعض المتغيرات. ويمكن صياغة مشكلة الدراسة الحالية في التساؤلات التالية: 1 - ما الضغوط المهنية النوعية لمعلمي التربية الخاصـة في كل من البيئة الثقافية السعودية والمصرية:؟

r - هل تختلف الضغوط المهنية لمعلمي التربية الخاصـة باختلاف البيئة الثقافية (السعودية/ المصرية)، وفئة الإعاقة التي يعمل معها المعلم (عقلية وتوحد/ بصرية/ سمعية)؟ r - هل تختلف الضنوط المهنية لمعلمي التربية الخاصـة باختلاف البيئة الثقافية (السعودية)

$$
\text { المصرية)، وجنس المعلم (ذكور / إناث)؟ }
$$

ع - هل تختلف الضنوط المهنية لمعلمي التربية الخاصـة باختلاف البيئة التقافية (السعودية/

$$
\text { المصرية)، وخبرة المعلم (أقل من ه سنوات/ ه سنوات فأكثر)؟ }
$$

$$
\text { أهــــاف الـــر/سـة }
$$

تهدف الدراسـة الحالية إلى استقصـاء الضغوط المهنية لمعلمي التربية الخاصـة في كل مـن البيئة الثقافيـة السـعودية والمصـرية، ومعرفـة الفروق في نوعيـة تلك الضـغوط في هـاتين البيئتين تبعاً لمتغيرات فئة الإعاقة التي يعمل معها المعلم، وجنسه، وسنوات خبرته. 
1 - ندرة الدراسات عبر الثقافية التي تتتاول الضغوط المهنية لمعلمي التربية الخاصة في

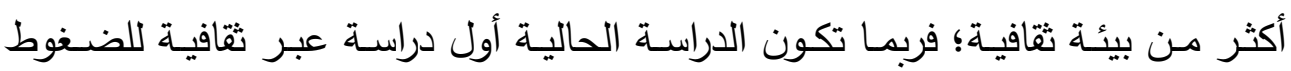

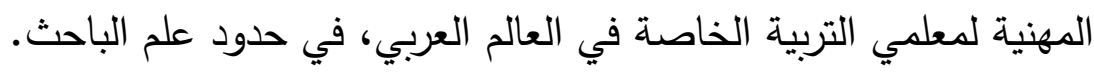

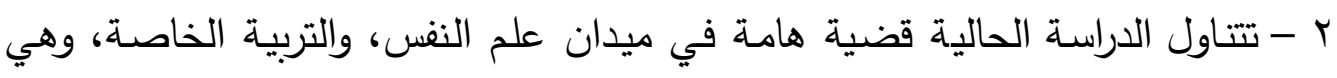
الضغوط المهنية التي يتعرض لها معلمو التربية الخاصة. r - تعارض نتائج الدراسات السابقة مع بعضها البعض.

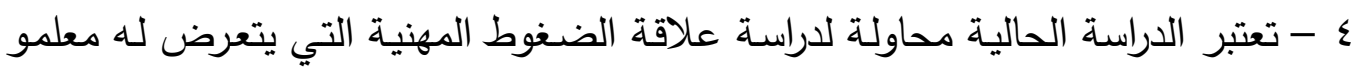

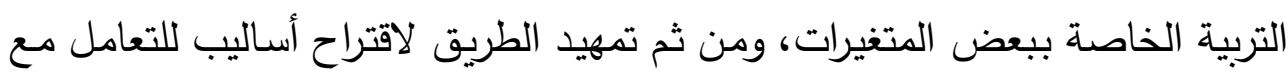

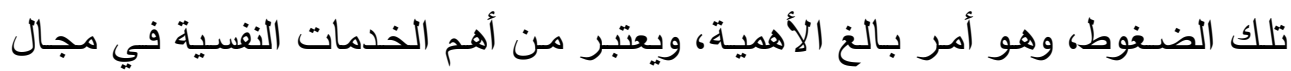

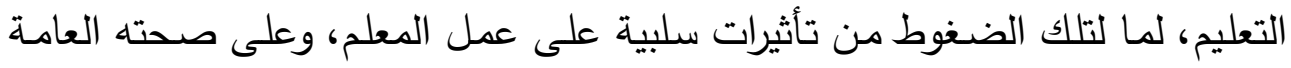

وصحته النفسية.

$$
\begin{aligned}
& \text { حـدود الــر/ســة } \\
& \text { ا - البعــــ البشـري }
\end{aligned}
$$

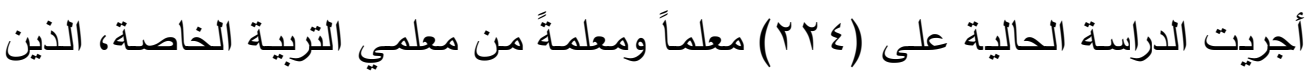

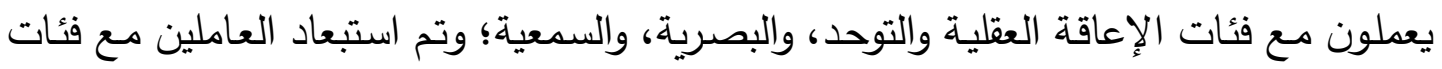

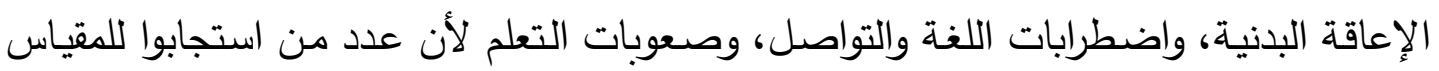

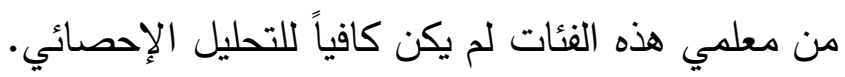

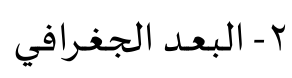

يعمل أفراد العينة في البيئة السعودية في مدارس ومعاهد التربية الخاصـة في المدينة

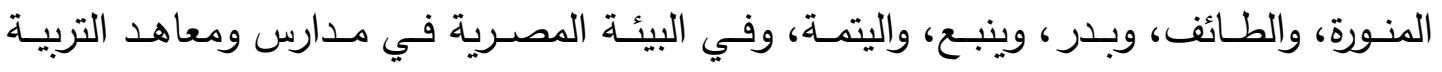

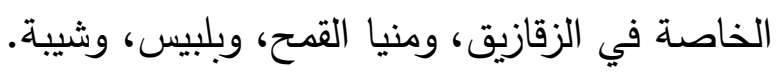
ب- البعـد الزمني

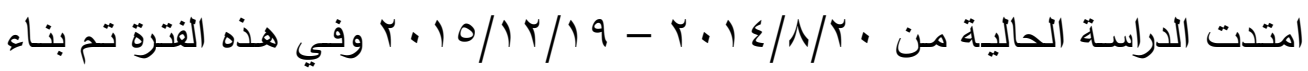
المقياس وتحكيمه وتقنينه وتطبيقه وتحليل النتائج إحصائياً. 


$$
\text { مصطلحسات الــر/ســة }
$$

1- الضغوط المهنية لمعلم التربية الخاصة

هي الخبرات التي يتعرض لها معلم التربية الخاصـة أثناء عمله، والمتعلقة بخصائص الأطفال ذوي الاحتياجات الخاصة، وطبيعة العمل معهم، والعلاقة بأولياء أمورهم، وبيئة العمل، والعلاقة بالزملاء والمدراء، والتي تؤثر سلباً على توافقه، وعلى أدائه لعمله، والتي يقيسها مقياس الضغوط المهنية لمعلمي التربية الخاصة.

$$
\text { r - ذوو الاحتياجات الخاصة }
$$

هم الأفراد الذين يختلفون عمن يطلق عليهم لفظ عادي أو سوي في النواحي الجسمية أو العقليـة أو الاجتماعيـة أو النفسية أو المزاجيـة إلى درجـة تستوجب عمليات التأهيل الخاصـة حتى تصل إلى استخدام أقصى ما تسمح به قدراتهم ومواهبهم. (عبدالمعطي، وأبو قلة، Y I • Y، 1 1). ويقصــ بهـم فـي الدراسـة الحاليـة ذوو الإعاقـة العقليـة والتوحـد، وذوو الإعاقـة السـمعية والبصرية الملتحقون بمدارس التربية الخاصة.

$$
\text { r - معلم التربية الخاصية }
$$

هو المعلم الذي يعمل مع أي فئة من فئات ذوي الاحتياجات الخاصـة. وتقتصر الدراسـة الحالية على معلمي فئات الإعاقة العقلية، والبصرية، والسمعية، والتوحد.

$$
\text { ع - دراسة عبر ثقافية }
$$

هـي الدراسـة التي تتــاول ظـاهرة معينـة في أكثر مـن ثقافـة؛ والدراسـة الحاليـة تتــاول الضغوط المهنية لمعلمي التربية الخاصة في البيئة الثقافية السعودية والمصرية.

$$
\text { الإطلار النظري والدر/سات السابقة }
$$

لا تخلو الحيـاة من هموم، ولا تخلو أي مهنـة من ضـغوط. ومهنـة التدريس من أكثر المهـن ضـغوطاً. والتـدريس لـذوي الاحتياجـات الخاصـة يلقـي على كاهـل المعلمين بضـغوط إضافية، فمعلمو التربية الخاصة على خطر عظيم من استحواذ الضغوط عليهم، وتمكنها منهم؛ (Brunsting, Sreckovic, \& لأن ظروف عملهم أقرب للضـغوط، وأكثر انحيازاً إليها ونظـراً لأن مـدارس التربيـة الخاصـة تخـدم طلابـاً ذوي احتياجـات أساسـية 
وجوهرية، ولديها بيئات عمل تختلف عن مدارس العاديين التقليدية، فإنها تمثل مجموعة فريدة من مصادر الضغوط بالنسبة للمعلمين (Lawson, 2011). ويواجه معلم التربية الخاصة في عمله العديد من المواقف الضاغطة لا سيما في الدول النامية (البخيت، وعمر، 11 (ب). وعلى الرغم من ذلك فإن الضغوط التي يتعرض لها معلمو التربية الخاصـة لم تحظ إلا بقدر قليل من اهتمام الدراسات والأبحاث (Lazuras, 2006). وبينما هناك ثراء في التراث الذي يركز على لهى

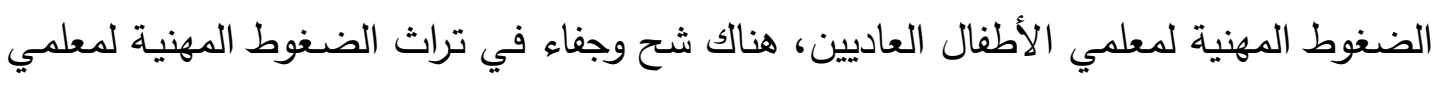
التربية الخاصـة. (Lawson, 2011). 2014) وهناك غياب لتراث الضغوط المهنية لمعلمي التربية الخاصة عبر البيئات الثقافية المختلفة. وتعرف الضغوط بأنها أي مثيرات أو تغيرات في البيئة الداخلية أو الخارجية، بدرجة من

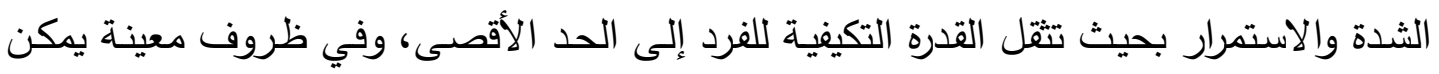

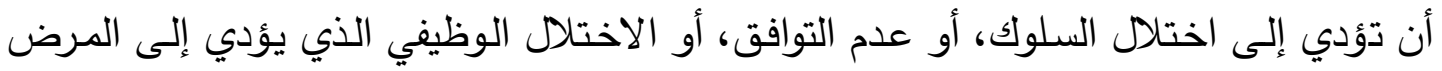

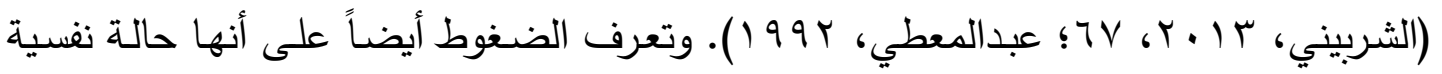

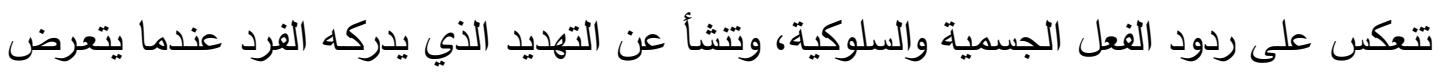
للمواقف الضاغطة في البيئة المحيطة (السمادوني، بـ99 (1)، 0؛ وتحدث الضغوط المهنية نتيجةً للتفاعل بين الأحداث التي تسبب القلق والإزعاج وعدم

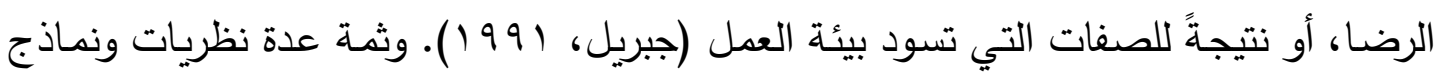

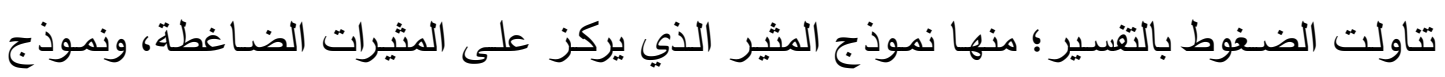

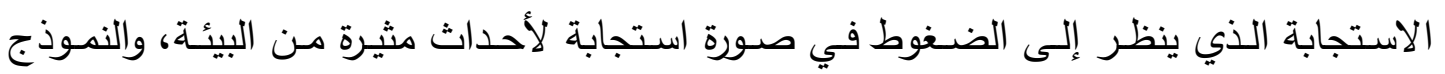

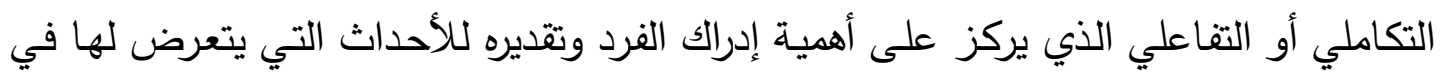

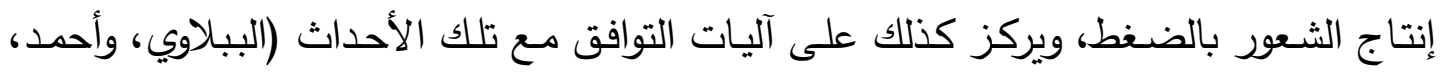

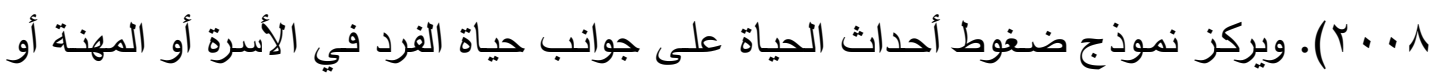
الأحداث التي تتتوع في قدرتها على إنتاج الضغوط. ويشير النموذج إلى أن الحجم الكلي للتأثير

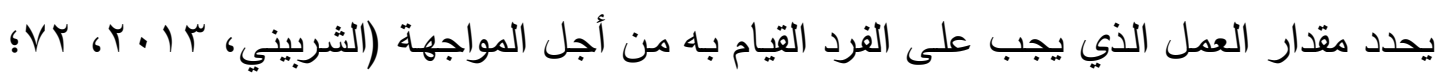

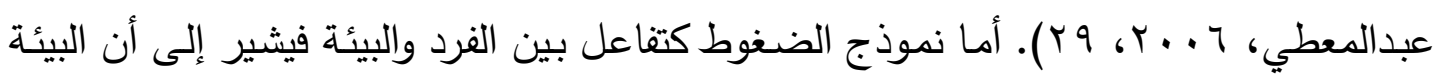


تؤثر في الفرد، وهو بدوره يؤثر فيها بطريقة تبادلية، وأن أساليب مواجهة الضغوط تتحدد في ضـوء تقدير الفرد للموقف. ويركز النــوذج على دور العوامـل المعرفيـة في تفسير الحـدث

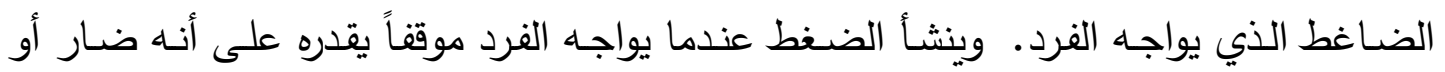
مهدد لتوافقه، وتحدث الضـغوط عندما تزيد المطالب البيئية عن قدرات الفرد على المواجهـة

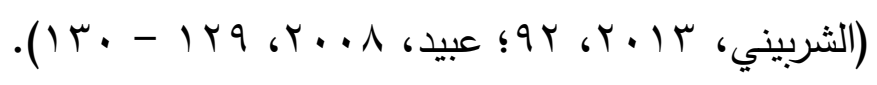

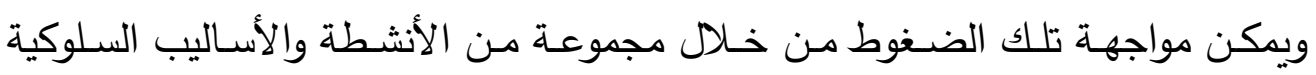

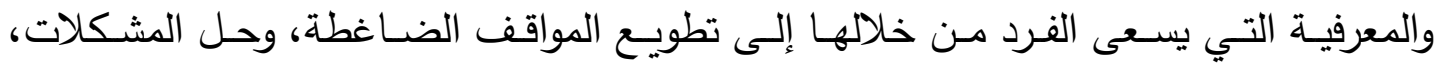

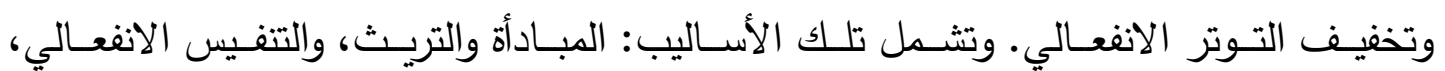
والاسترخاء، وإعادة التنسير الإيجابي، والتنكير الإيجابي، والبحث عن الدعم الاجتماعي. ويمكن

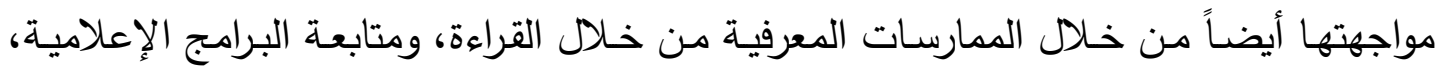

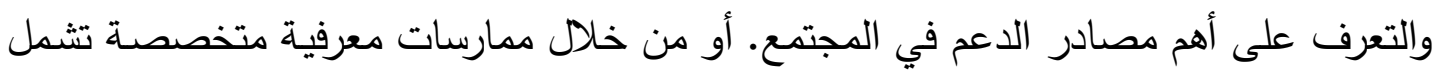
معرفة المزيد عن الشكلة، وكيفية مواجهتها، وحضور الندوات والبرامج التدريبية المتعلقة بها. أو من خلال ممارسات مختلطة تثمل استخدام أساليب متتوعة لمواجهة الضغوط دون التركيز

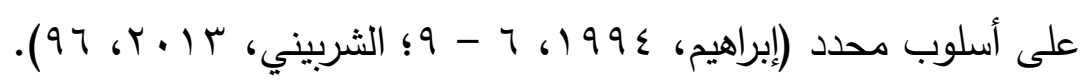
ولعل من الأسـاليب الناجحة الناجعة في مواجهة الضـغوط معرفـة أسبابها واستقصـاء

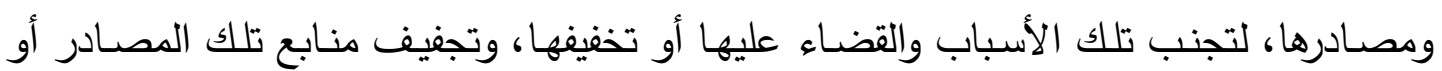
تضييق روافدها. وتثير أدبيات التربية الخاصـة إلى أن الضـغوط المهنية لدى معلمي التربية

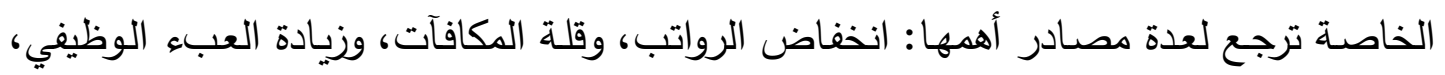
وغـوض الدور، وصـراع الـدور، وانخفـاض دافعيـة التلاميـذ ذوي الاحتياجـات الخاصـة نـــ الدراسـة، وصـوبة ضبط الصـف، وقلـة فرص الترقي الـوظيفي وانخفـاض الدعم، وتعـارض العلاقات مع الزملاء والمدراء والموجهين، وعدم المشاركة في القرارات المدرسية، وتدني المكانة

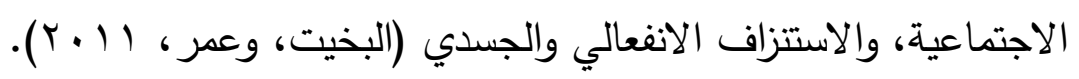
وقد حاولت العديد من الدراسات السابقة استقصـاء مصادر الضغوط المهنية وعلاقتها ببعض المتغيرات. وفيما يلي عرض لتلك الدراسـات من الحديث إلى القديم مستهلاً بدراسـة 
الزبون، والدبابنة، وأحمد Al-Zboon, Al_Dababneh, \& Ahmad (2015) التي هدفت إلى بحث مستوى جودة حياة العمل لاى معلمي التربية الخاصة بالأردن. وتكونت عينتها من

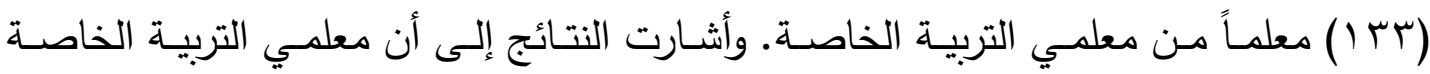
صنفوا احترام المدراء والزملاء على أنه أعلى مفردات مقياس جودة حياة العمل، في حين صنفوا المشاركة في اتخاذ القرارات في المدرسة على أنها أقل مغردات مقياس جودة حياة العمل. وكذلك الك أشارت النتائج إلى عدم وجود فروق دالة إحصائياً بين متوسطات درجات جودة حياة العهل تعزى لمتغيرات الجنس، والمستوى التعليمي، ونوع المدرسـة (مدارس الدمج) مدارس التربيـة

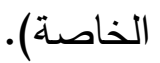

وسعت دراسـة خوساينوفا (2015) Khusainova الضـغوط المهنية وخصائص التواصل في شخصية المعلم على زيـادة خبرة التدريس. وأثـارت النتائج إلى التأثير البارز للضغوط المهنية على كفاءة شخصية المعلم، وأثـارت أيضاً إلى أن

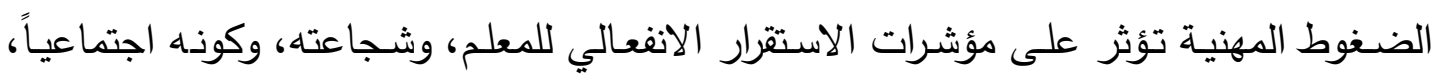
وكونه عملياً، وقدرته الإبداعية، واستقلاله في علاقاته. وكذلك تشير النتائج إلى أن الاستقرار الانفعالي يمثل أحد أهم العوامل في التعامل مع الضغوط. Cancio, Albrecht, \& Johns (2013) واستهدفت دراسة كانسيو، وألبرشت، وجوني تحديد إدراك معلمي الأطفال ذوي الاضطرابات الانفعالية والسلوكية لتعريف، ومدى، وأهميـة الدعم الإداري في تحديد العوامل المؤثرة على استمرارية المعلم في عمله في ميدان التربيـة الخاصـة. وقد تم إجراء مسح لمعلمي الأطفال ذوي الاضطرابات الانفعاليـة والسلوكية لدراسـة العلاقة بين إدراك المعلم للاعم الإداري والضـوط المهنية التي يتعرض لها، والرضـا الوظيفي، والعزم على مواصلة العمل في مجال التربية الخاصـة. وأشـارت النتائج إلى وجود ارتباط دال

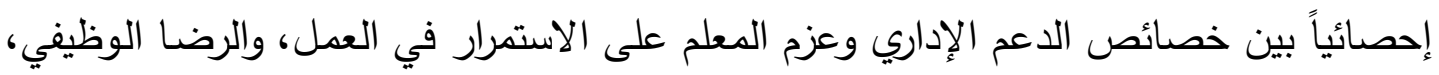
والنظرة الإيجابية للمدرسة، والتقدير والثقة. كما أثارت إلى أن سلوكيات إدارية معينة قد أثرت على قرار المعلم بالاستمرار في العمل مع الأطفال ذوي الاضطرابات الانفعالية والسلوكية. 
Hamama, Ronen, في حين هدفت دراسة همامة، رونين، وشاتشار ، وروزينبوم Shachar, \& Rosenbaum (2013)

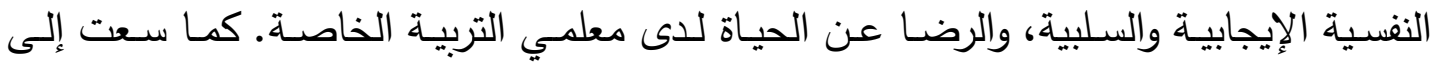
استكثـاف المصـادر التي ربما تستثير المشـاعر الإيجابية والرضـا عن الحياة، بما في ذلك الضبط الذاتي كمهارة شخصية والدعم المدرك الذي يقدمـه الزملاء، والأخصائيون النفسيون،

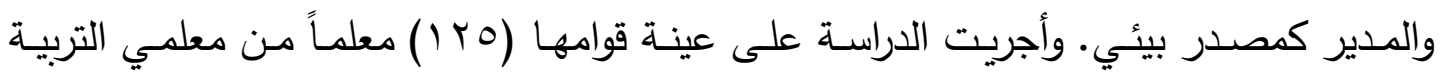
الخاصة. وتشير النتائج إلى وجود ارتباط موجب دال إحصائياً بين مستويات الضغوط المهنية

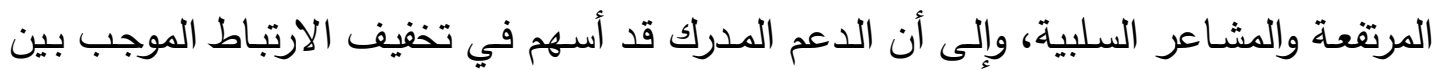

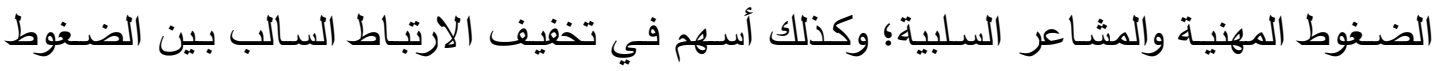
المهنية المشاعر الإيجابية والرضا عن الحياة بين المعلمين.

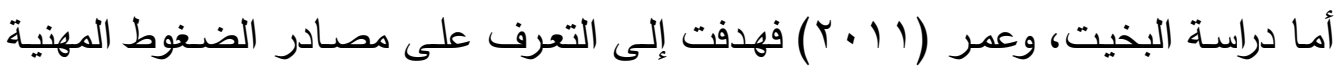

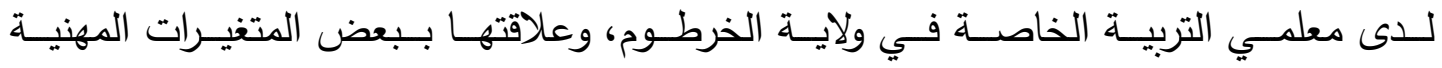

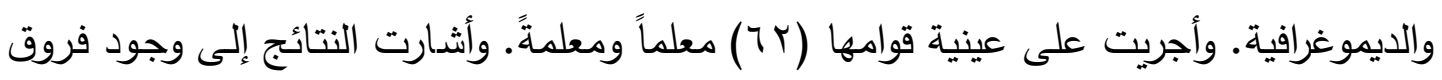

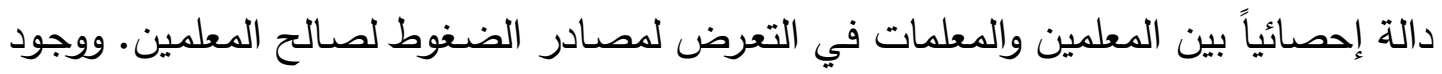
فروق دالة إحصائياً بين معلمي ذوي الإعاقة السمعية ومعلمي ذوي الإعاقة العقلية في التعرض الترصن

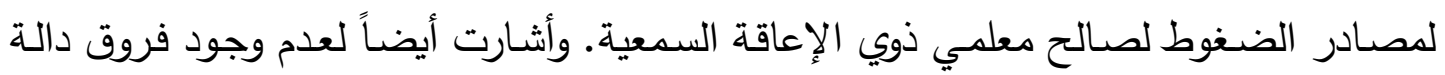
إحصائياً في مصادر الضغوط تعزى للخبرة أو اختلاف المؤهل الدراسي.

Kodavatiganti, \& Bulusu وكان الهدف من دراسة كودافاتيجانتي، وبولوسو

(2011) فهم ظاهرة الضغوط المهنية بين المعلمين في المؤسسات التعليمية العامة والخاصـة في حيدر أباد في الهند، ومن ثم فهم العوامل الأساسية التي تؤدي إلى الضغوطن لهن وأظهرت

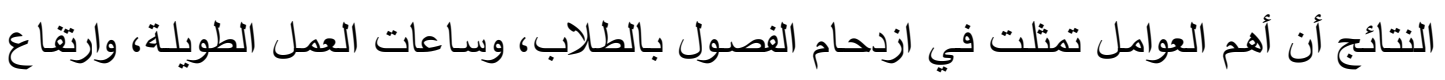
سقف التوقعات من قبل آباء الطلاب، ونقص الموارد، وافتقار الطلاب للأهداف الواضحة. بينما تمثل الهدف من دراسة بوش Bush (2010 في استكشاف خبرات معلمي التربية الخاصـة بخصـوص تحديات العمل، وإدراكهم للضـنوط المهنيـة، ودراسـة فائـدة نــوذج ميـول 


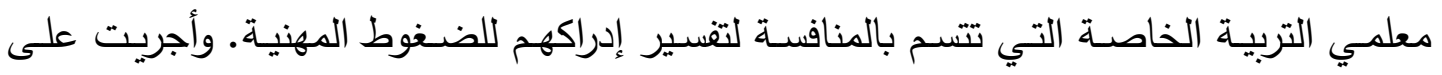
عينة قوامها (9 (1) معلماً من معلمي التربية الخاصة من مناطق ريفية وحضرية في شرق ولاية واشنطن. واستخدم أسلوب المقابلة لجمع البيانات. وأظهرت النتائج أن خبرات معلمي التربيـة الخاصة قد أسهمت في تعديل نموذج الميول التي تتسم بالمنافسة لديهم.

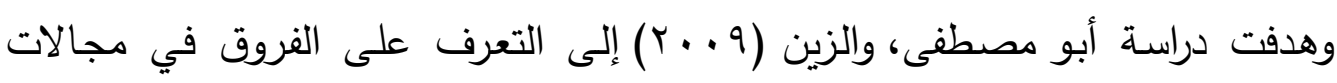
مصادر ضغوط العمل لاى معلمي التربية الخاصة في ضوء بعض المتغيرات. وتكونت عينة

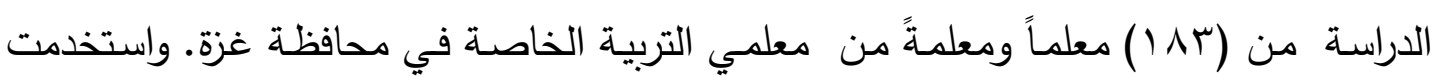

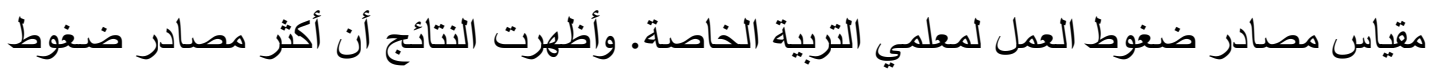

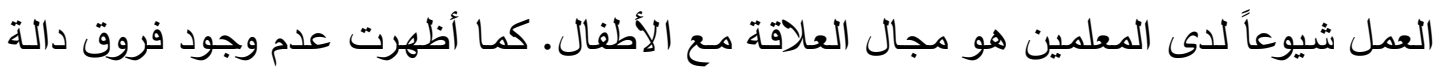
إحصائياً في مصادر ضغوط العمل تبعاً لمتغيرات الجنس، أو الحالة الاجتماعية أو المؤهل

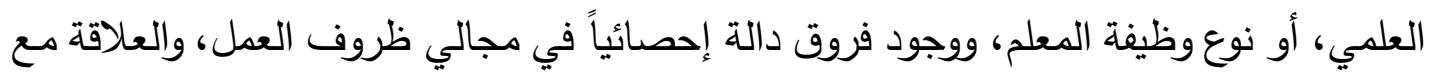
الأطفال؛ تبعاً لمتغير نوع إعاقة الطفل، لصالح أطفال صعوبات التعلم. أما دراسة شايمان (2009) Shyman فهدفت إلى استكثاف مصادر الضغوط المهنية لاى مساعدي المعلمين في التربية الخاصة وعلاقتها بمشكلات الصحة النفسية لديهم. وأجريت

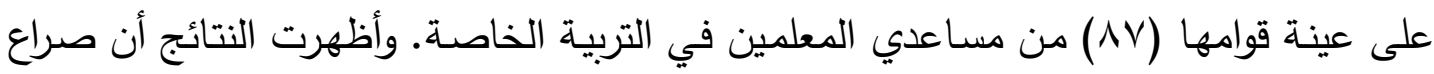

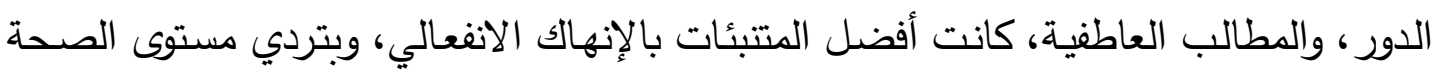
النفسية، وتدني مستوى الحيوية.

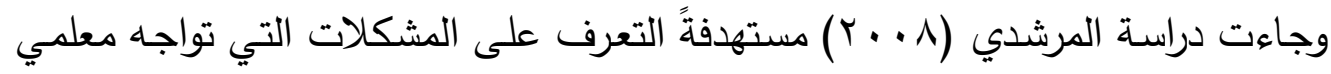
ذوي صعوبات التعلم فيما يتعلق بالإدارة المدرسية، والتجهيزات المكانية، والوسائل التعليمية،

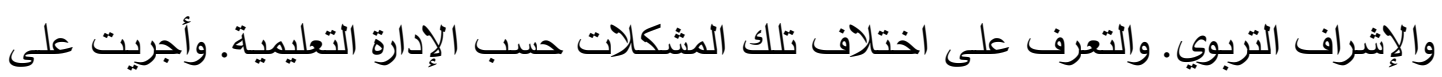

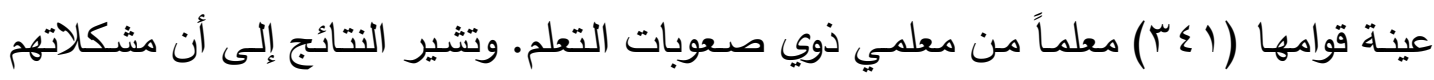
تتعلق بتعاون معلم الفصل العادي معهم، وقلة سنوات الخبرة، وبعد مكان العمل. وتبلور الهدف من دراسة ديكرسون Dickerson (2008) في تحديد ما إذا كانت هناك

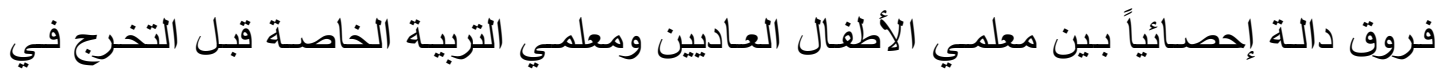


الضغوط وفعالية الذات أثناء وبعد فصل دراسي. وأجريت على عينة من طلاب أربع جامعات من

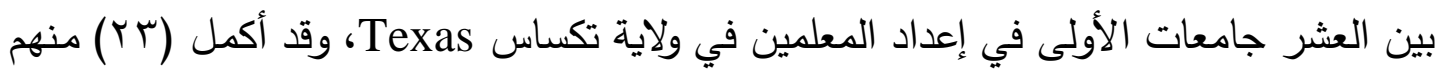

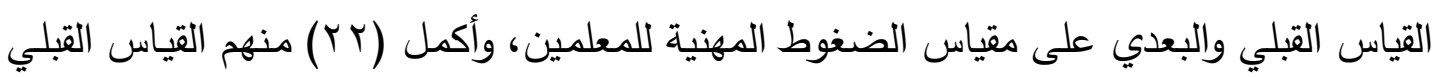

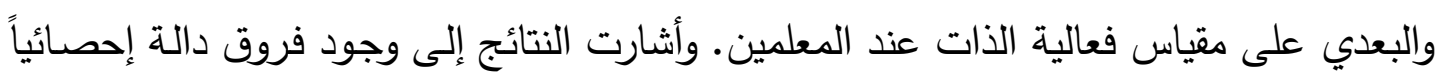
في الضغوط المهنية وفعالية الذات لدى الطلاب من معلمي الأطفال العاديين في القياسين القبلي

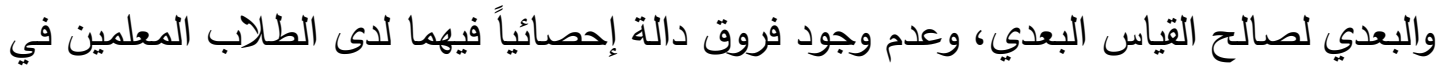

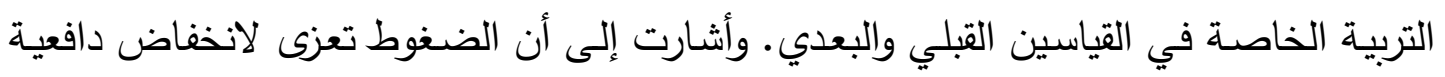
الطلاب، وعدم محاولتهم استثمار أقصى قدراتهم.

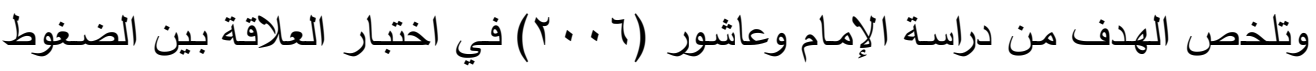

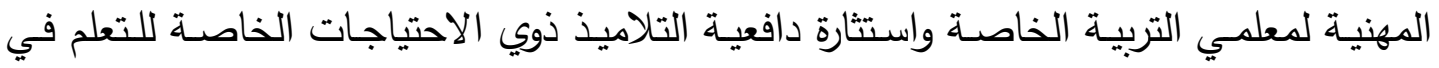

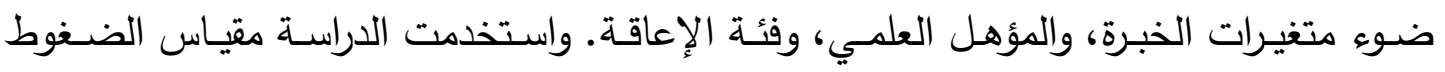

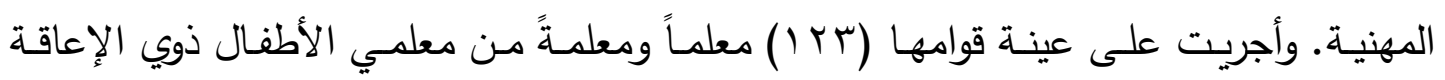

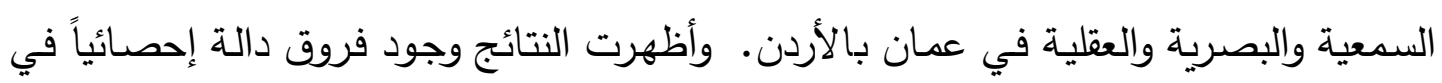

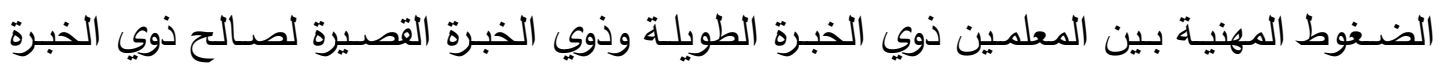

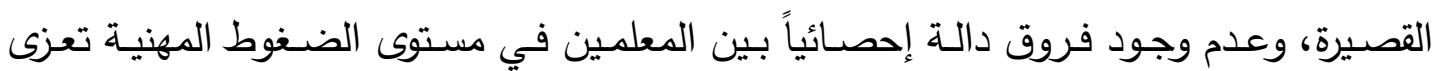
للمؤهل العلمي، أو فئة الإعاقة التي يتعامل معها المعلم.

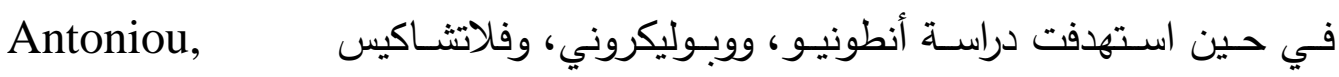
تحديد مصادر الضغوط المهنية لمعلمي المدارس Polychroni, \& Vlachakis (2006)

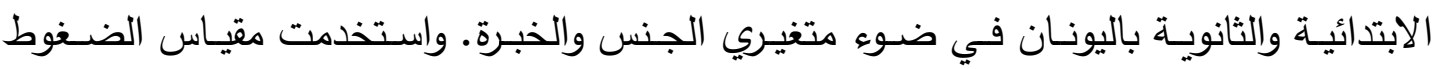

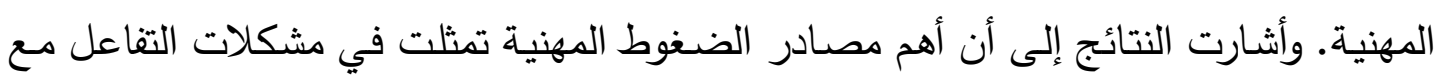

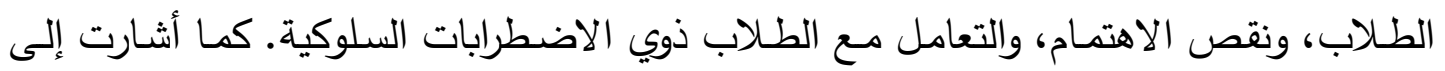

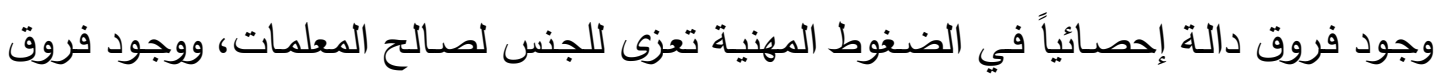
تعزى للخبرة لصالح ذوي الخبرة القصيرة؛ في حين كانت الفروق لصالح ذوي الخبرة الطويلة في بعد الدعم الحكومي. أما دراسة لازوراس Lazuras (2006) فقد استهدفت استكثاف الفروق في مستويات الضغوط المهنية وآثارها السلبية على الصحة البدنية لاى معلمي الأطفال العاديين ومعلمي 
التربية الخاصـة، ومحاولة فهم عملية الضغوط للى معلمي التربية الخاصـة. وتكونت عينة الدراسة من (• V) معلماً من معلمي التربية الخاصـة ومعلمي الأطفال العاديين في إحدى المدن

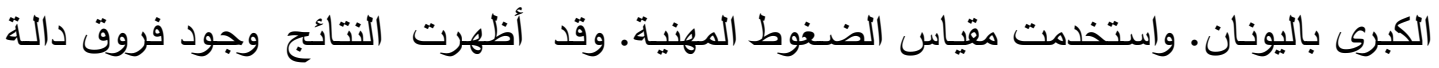

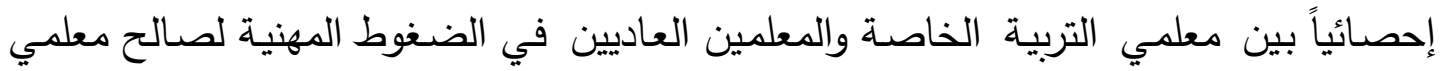
التربية الخاصة، وأشارت إلى أن تلك الضغوط تؤثر سلباً على صحة المعلمين. وهدفت دراسـة بـلاش، وبايوتروسكي Plash \& Piotrowski (2006) إلى معرفـة العوامل التي تؤثر على إنهاك، وتسرب معلمي التربية الخاصـة في ولاية ألاباما Alabama. وتكونت العينة من (•V) معلماً من ذوي الكفاءات العالية. واستخدمت مقياس الرضا الوظيفي.

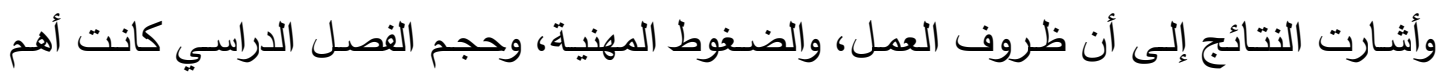
أسباب الإنهاك أو التسرب من مهنة التدريس.

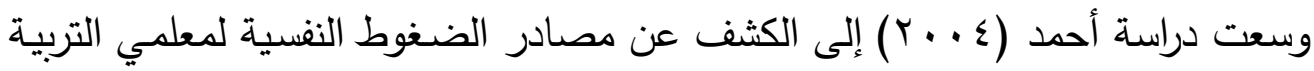

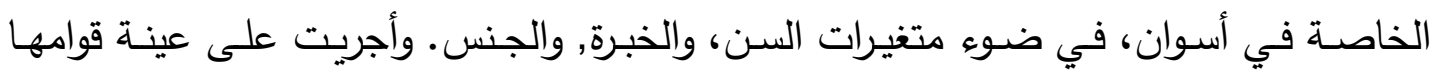

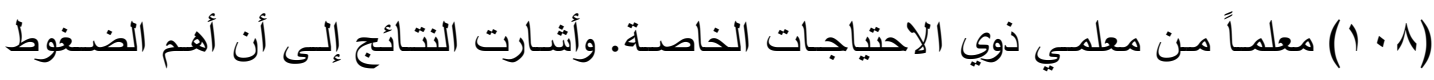
المهنية التي يتعرض لها المعلمون تتعلق بظروف بيئة العمل، وخصائص التلاميذ، والمنهج.

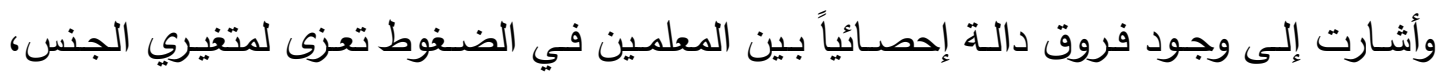
والعمر ، وعدم وجود فروق دالة إحصائياً بينهم تعزى للخبرة.

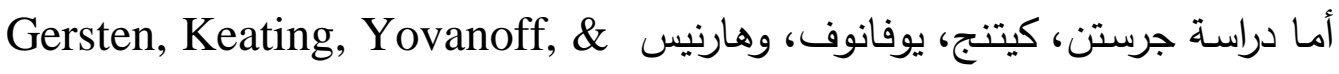

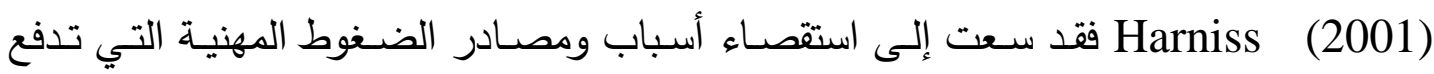
معلمي التربية الخاصة إلى ترك مهنتهم، والعوامل التي من شأنها تعزيز الرضا الوظيفي لديهم

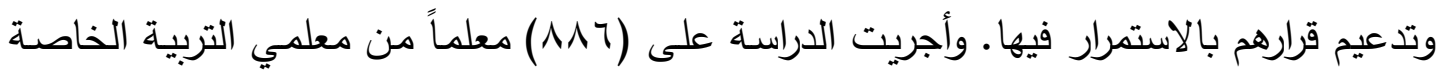

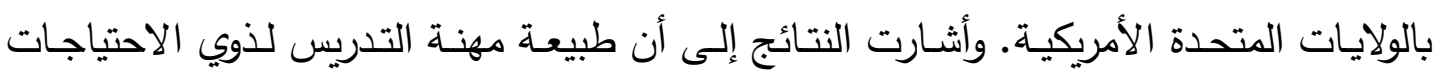

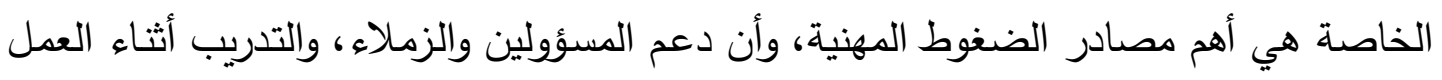
من أهم العوامل التي تساعد على الرضا الوظيفي. وكان الهدف من دراسة ساتون، وهابرتي (2001) Sutton, \& Hubrrty اختبار العلاقة بين الضـغوط المهنية والرضـا الوظيفي لدى عينة من معلمي الأطفال العاديين وذوي 


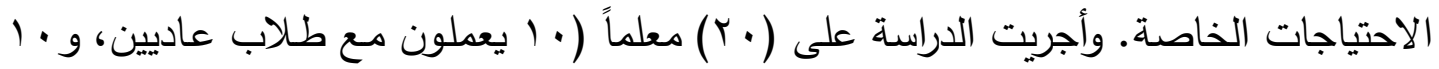

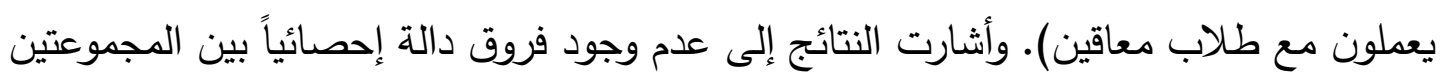

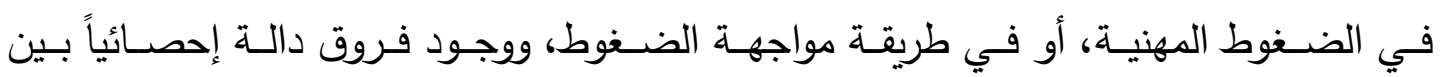
المجموعتين في الرضا الوظيفي لصالح معلمي الأطفال ذوي الاحتياجات الخاصة.

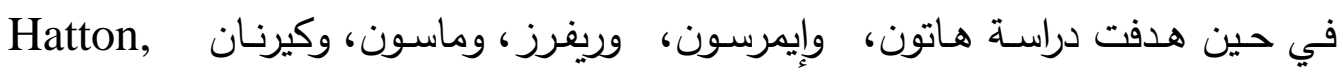
Emrson, Rivers, Mason and Kiernan (1999) النفسية لدى المعلمين وعلاقته ببعض المتغيرات. وأشارت نتائج الدراسة إلى وجود ارتباط بين

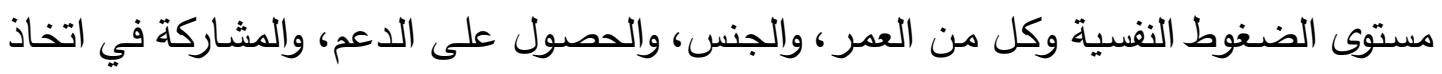
القرارات داخل الددرسة، والنظرة الاجتماعية نحو مهنة التدريس. وسعت دراسة الكذن (1997 ) إلى التعرف على الضغوط المهنية لمعلمي التربية الخاصة وعلاقتها ببعض المتغيرات الديموغرافية. وأجريت على عينة قوامها (1M (1) معلمًا ومعلمةً. وأظهرت النتائج وجود علاقة طردية بين مستوى الضغوط ومتغيري المستوى التعليمي، والخبرة التعليمية، ووجود فروق بين المعلمين في مستوى الضغوط النفسية تعزى لفئة الإعاقة التي يقوم المعلم بالتدريس لها لصالح معلمي الإعاقة السمعية.

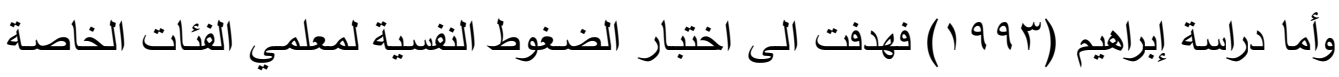

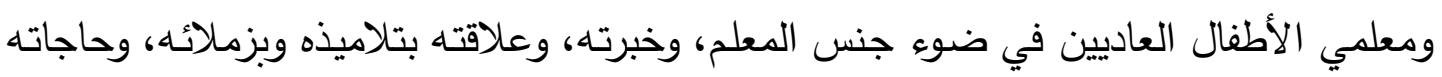

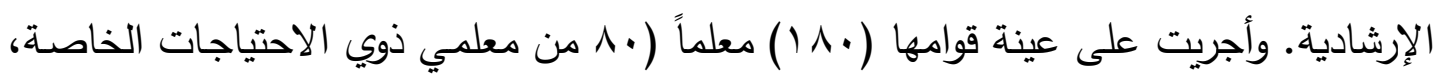

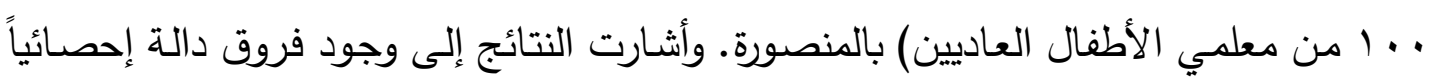
في الضغوط لصالح معلمي ذوي الاحتياجات الخاصة، ووجود ارتباط سالب دال إحصائياً بين مدة خبرة المعلم والضغوط النفسية لمهنـة التدريس، ووجود ارتباط سـالب دال إحصـائياً بين التين

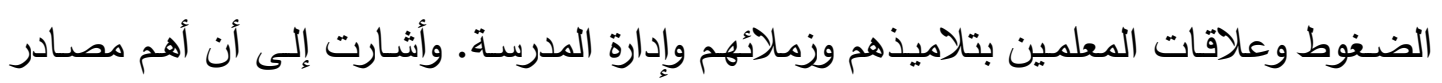

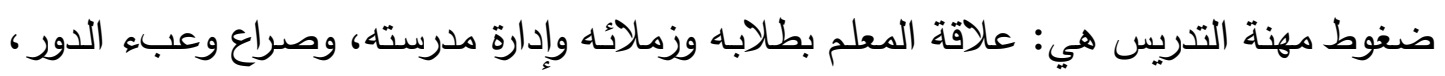
واتجاهات المجتمع نحو هذه المهنة. وسعت دراسـة مينر، ولييتش Minner, ＆ Lepich (1993) إلى الكشف عن الضـوط المهنيـة لمعلمي التربيـة الخاصـة وعلاقتها بمتغيري الجنس ومكان العـل (المدينـة/ 
الريف). وأجريت على عينة قوامها (70 1 ) معلماً من معلمي التربية الخاصة بالولايات المتحدة

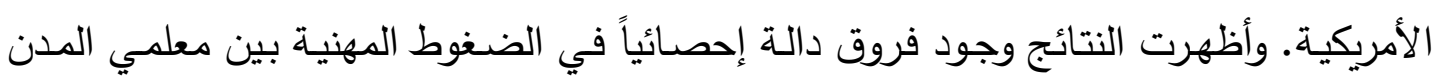
ومعلمي الريف لصالح معلمي الددن، ووجود فروق بين المعلين والمعلمات لصالح المعلمات. وكذلك هدفت دراسة راسل، وويلي Russell, \& Wiley (1993) إلى التعرف على الضـغوط المهنيـة لمعلمي التربيـة الخاصـة في المنـاطق الريفيـة، وعلاقتها بفئة إعاقة الأطفال الذين يتم التدريس لهم. وأجريت على عينة قوامها (ع ا 1) معلماً من معلمي التربية الخاصـة. وخلصت النتائج إلى عدم وجود فروق دالة إحصائياً بين المعلمين في الضغوط المهنية تعزى لفئة إعاقة الأطفال، وعدم وجود فروق بينهم في الرضا الوظيفي، والمناخ التعليمي، والحصول

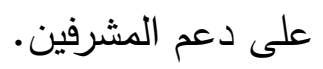

وتمثل الهدف في دراسة اليوسفي (•99 (19) في الكثف عن ضغوط العمل لاى المعلمات في ضوء متغيري المستوى الاجتماعي، والخبرة. وتكونت عينتها من (r^) معلمَة. وأظهرت النتائج وجود ارتباط سالب دال إحصائياً بين ضغوط العمل والتوافق، ووجود فروق في ضغوط التون العمل تعزى لمتغير الخبرة لصالح ذوات الخبرة الطويلة. تعقيب على الدراسات السابقة

اختلفت نتائج الدراسات السابقة فيما يتعلق بالمتغيرات التي تتاولتها. وعلى سبيل المثال كان لمتغير فئة الإعاقة التي يعمل معها المعلم نصيبه وحظه من اختلاف نتائج الدراسات السابقة بشأنه؛ فقد أشارت نتائج دراسة راسل، وويلي (1993) Russell, \& Wiley، والإمام وعاشور

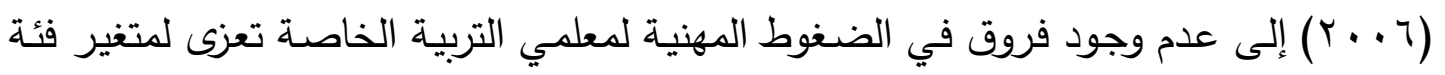

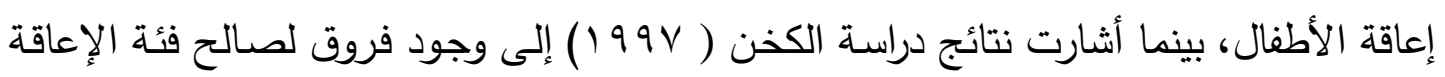
السمعية. وظهرت التباينات والاختلافات واضحةً جليةً في متغير الجنس؛ فقد أشارت دراسة أبو مصطفى، والزين (9 + . +) إلى عدم وجود فروق دالة إحصائياً بين المعلمين والمعلمات في الضغوط المهنية، في حين أشنارت دراسات أخرى إلى وجود فروق تعزى لمتغير الجنس، وعاد

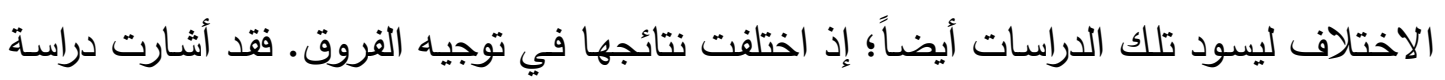




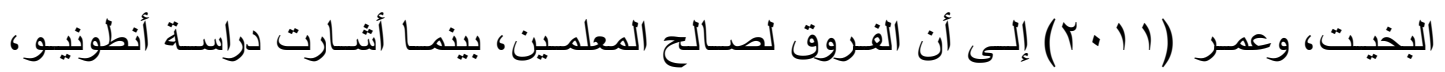
بوليكروني، وفلاتشاكيس(2006) Antoniou, Polychroni, \& Vlachakis بودراسة مينر ولييتش، (1993) Minner, \& Lepich, إلى أن الفروق كانت لصالح المعلمات. كما كان الاختلاف سيد النتائج فيما يتعلق بمتغير الخبرة. فقد أشارت دراسة أحمد (ع . ب ب) إلى عدم وجود فروق بين المعلمين في الضغوط المهنية تعزى لمتغير الخبرة، بينما أشارت نتائج دراسات أخرى لهير إلى وجود فروق تعزى لمتغير الخبرة؛ واختلفت هذه الدراسات في توجيه الفروق؛ إذ أشارت دراسة أنطونيو، وبوليكروني، وفلاتثاكيس (2006) Antoniou, Polychroni, \& Vlachakis

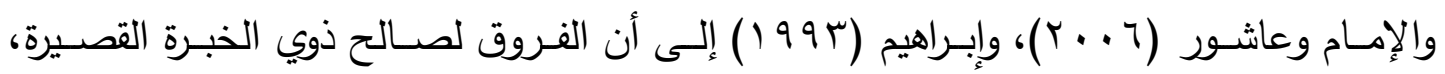
في حين أشارت دراسة الكخن (1997 ()، واليوسفي ( •99 1) إلى أن الفروق لصالح ذوي الخبرة الطويلة.

$$
\text { فــروض الــراســة }
$$

1 - توجد فروق جوهرية في نوعية الضغوط المهنية لمعلمي التربية الخاصة في كل من

$$
\text { البيئة الثقافية السعودية والمصرية. }
$$

r - توجد فروق دالـة إحصـائياً في الضـغوط المهنيـة لمعلمي التربيـة الخاصـة تعزى لاختلاف البيئة التقافيـة التي يعمل فيها المعلم، وفئة الإعاقـة التي يعهل معهـا لصالح البيئة الثقافية المصرية ولصالح فئة الإعاقة السمعية".

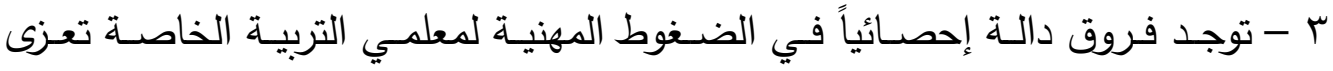
لاختلاف البيئة الثقافية التي يعمل فيها المعلم، وجنس المعلم لصالح البيئة الثقافية

$$
\text { المصرية ولصالح الذكور • }
$$

ع - توجد فروق في الضـغوط المهنيـة لمعلمي التربيـة الخاصـة تعزى لاختلاف البيئة الثقافية التي يعمل فيها المعلم، وسنوات خبرة المعلم لصالح البيئة الثقافية الدصرية ولصالح ذوي الخبرة القصيرة. 


$$
\begin{aligned}
& \text { طـريقــة وإجـراء/ت الــر/ســة } \\
& \text { منه-ج الـدراســة }
\end{aligned}
$$

استخدم الباحث المنهج الوصفي، وتم استخدام مقياس الضغوط المهنية لـعلمي التربية الخاصـة، واللذي تم تطبيقـه على عينـة مـن معلمـي التربيـة الخاصـة في البيئتين السـعودية والمصرية، ولتحليل البيانات استخدم الباحث اختبار "ت" Test "T" واختبار "تحليل التباين"،

واختبار "شيفيه للمقارنات البعدية" "Scheffe".

عينـة الـدراســة

أجريت هذه الدراسة على عينة قوامها (ع Y ) معلماً ومعلمةً من معلمي التربية الخاصة

بالمملكة العربية السعودية وجمهورية مصر العربية، بعد استبعاد الاستمارات التي لم تف بشروط التحليل الإحصائي، واستبعاد العاملين مع فئات الإعاقة البدنية، واضطرابات اللغة والتواصل، وصـعوبات التعلم لعـدم كفايـة أعداد معلمي هذه الفئـات الذين استجابوا للمقيـاس للتحليـل الإحصائي. وجدول (1) يلخص توزيع أفراد العينة حسب متغيرات الدراسة.

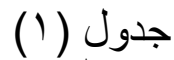

\begin{tabular}{|c|c|c|c|c|c|}
\hline العدد & Ie & & العذد & البعد & \\
\hline $1 \leqslant V$ & العقلية والتوحد & \multirow{4}{*}{ فئة الإعاقة } & $1 \leq 9$ & ذكور & \multirow{2}{*}{ الجنس } \\
\hline$r v$ & البصرية & & vo & إناث & \\
\hline \multirow[t]{2}{*}{$\varepsilon$} & السمعية & & 71 & أقل من ه سنوات & \multirow{2}{*}{ الخبرة الخ } \\
\hline & & & r & ه سنوات فأكثر & \\
\hline
\end{tabular}

توزيع أفر اد العينة على متغير ات الدراسة

$$
\text { أدوات الــدراســة }
$$

اسـتخدم الدراســة الحاليـة مقيـاس الضــوط المهنيـة لمعلمـي التربيـة الخاصــة (إعـداد

الصــورة الأوليــة: اطلع الباحث على المراجع والدراسـات المتصلة بالضـغوط المهنية، وأعد استمارة لاستقصاء الضغوط التي يتعرض لها معلمو التربية الخاصـة، وقام بتوزيعها على لهى

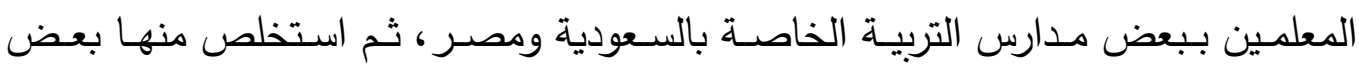


العبارات، وكذلك استفاد من بعض المقاييس التي وقف عليها في الدراسات السـابقة في إعداد الصورة الأولية للمقياس، والتي تكونت من (بهم) مفردة، موزعة على خمسة محاور هي: الضغوط المتعلقة بخصائص الأطفال ذوي الاحتياجات الخاصـة، والضغوط المتعلقة

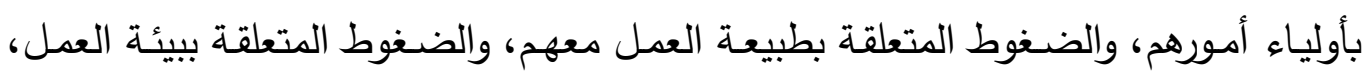
والضـغوط المتعلقة بالعلاقات المهنية بالمؤسسـة (العلاقة بالزملاء والمدراء). ثم عرضهها

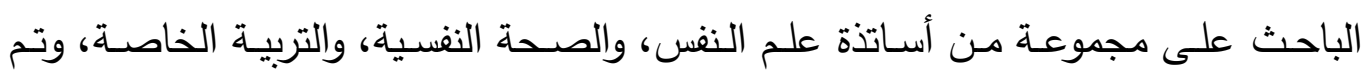

$$
\text { إجراء التعديلات التي نصحوا بها. }
$$

الصـورة قبـل النهائيـة: وتكونت من (Tـ ) مفردة. وتم تطبيقها على عينة استطلاعية قوامها ( ( 7) معلماً من معلمي التربية الخاصة للتأكد من صدق وثبات المقياس.

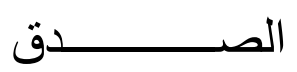

أ) صدق المحكمين: قام الباحث بعرض المقياس في صورته النهائية على مجموعة من الأساتذة

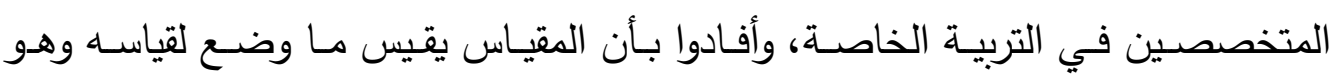
الضنغوط المهنية لمعلمي التربية الخاصـة. ووصلت نسبة اتفاق المحكمين حول عبارات الاستمارة إلى حوالي (19 \%) ومن ثم فإنه يتمتع بقدر كبير من الصدق. ب) الصدق التمييزي: تعتمد فكرة الصدق التمييزي على قدرة المقياس على التمييز بين فئتين مختلفين من الأفراد إذا تم تطبيقه عليهما. وقد تم تطبيق المقياس على عينة من معلمي

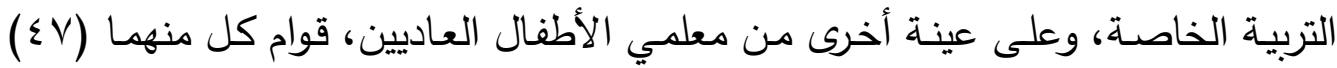

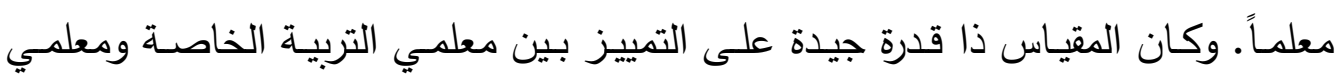

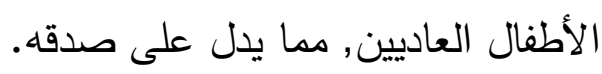

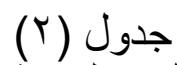
الفروق بين متوسطات درجات معلمي التربية الخاصة ومعلمي الأطفال العاديين

\begin{tabular}{|c|c|c|c|c|c|}
\hline مينتو ى الدلالة & 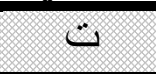 & $\varepsilon$ & 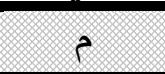 & $\dot{u}$ & المجمو عة \\
\hline \multirow[t]{2}{*}{$\ldots 1$} & \multirow[t]{2}{*}{$0.147-$} & .99 .1 & \&Y૫.Vq & $\leqslant V$ & معلمو التربية الخاصة \\
\hline & & $0 \wedge 7.11$ & T4.71 & $\leqslant V$ & معلمو الأطفال العاديين \\
\hline
\end{tabular}


الاتســــاق الــــداخلــــي

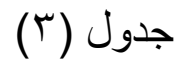

معاملات ارتباط درجات مفردات مقياس الضغوط المهنية لمعلمي التربية الخاصة بالدرجة الكلية

\begin{tabular}{|c|c|c|c|c|c|c|c|c|c|c|c|}
\hline الارنباط & ألمفرد & الارتباط & المفزد & الارنباط & المفرد & الارنباط & 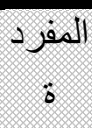 & الارنباط & | & الارنباط & ألمفرد \\
\hline $\begin{array}{c}* . . \\
* \\
*\end{array}$ & $\leqslant 1$ & $\begin{array}{c}* . r 4 \\
*\end{array}$ & r & $\begin{array}{c}* . .2 \wedge \\
*\end{array}$ & ro & $\begin{array}{c}* .00 \\
*\end{array}$ & IV & $\begin{array}{c}* . . \leqslant Y \\
*\end{array}$ & 9 & $\because$..ro & 1 \\
\hline * & $\varepsilon r$ & $\begin{array}{c}* . . \varepsilon \\
* \\
*\end{array}$ & $r \varepsilon$ & .ro & Y & $\begin{array}{c}* .7 \mathrm{~V} \\
*\end{array}$ & 11 & $\begin{array}{c}* .00 \\
*\end{array}$ & 1. & $\because l^{V-}$ & r \\
\hline $\begin{array}{c}* . . \\
* \pi T \\
*\end{array}$ & $\varepsilon r$ & $\begin{array}{c}* . r 4 \\
*\end{array}$ & ro & $\cdot r \leqslant-$ & rV & $\begin{array}{c}* . . \leq \Lambda \\
*\end{array}$ & 19 & *.ro & 11 & $\begin{array}{c}* . . \Gamma T \\
*\end{array}$ & $r$ \\
\hline $\begin{array}{c}- \\
\ldots .+\mu r\end{array}$ & $\varepsilon \varepsilon$ & $\begin{array}{c}* . . \text { \& } \\
*\end{array}$ & ry & $\begin{array}{c}* . . \leqslant V \\
*\end{array}$ & rA & $\because ., \wedge$ & $r$. & $\begin{array}{c}* .7 \\
*\end{array}$ & Ir & $* . .+q$ & $\varepsilon$ \\
\hline *..TO & $\leq 0$ & $\ldots 9-$ & TV & $\begin{array}{c}* . \text {. r } \\
*\end{array}$ & rq & $\because T V-$ & YI & . To & $1 \pi$ & $\begin{array}{c}* . . \Gamma T \\
*\end{array}$ & 0 \\
\hline \multirow[t]{3}{*}{$. .1 \leq-$} & $\leq 7$ &. $\mathrm{rT}^{-}$ & rᄉ & $*$. TO & $r$. & * & Yr & $\begin{array}{c}* . . \leqslant Y \\
*\end{array}$ & $1 \varepsilon$ & $\begin{array}{c}* . . r q q \\
*\end{array}$ & 7 \\
\hline & & $\begin{array}{c}* . . \leqslant 0 \\
*\end{array}$ & rq & $\begin{array}{c}* . \text {. To } \\
*\end{array}$ & r) & *..ro & r & $\begin{array}{c}* . . T r \\
*\end{array}$ & 10 & $\begin{array}{c}* . . \leq 7 \\
*\end{array}$ & V \\
\hline & & $\begin{array}{c}* . . \leq \varepsilon \\
*\end{array}$ & $\varepsilon$. & *. ro & rr & $\begin{array}{c}* .0 \leqslant \\
*\end{array}$ & $r \varepsilon$ & $\cdots v-$ & 17 & $\begin{array}{c}* . . \Gamma 4 \\
*\end{array}$ & $\wedge$ \\
\hline
\end{tabular}

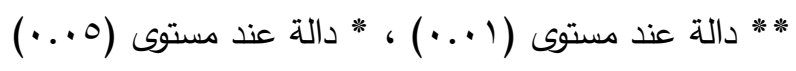

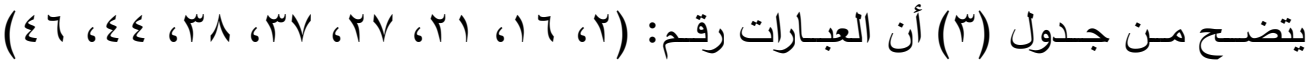

ليس لها قدرة تمييزية، ومعاملات ارتباطها غير دالة إحصائياً، ولذا تم استبعادها من المقياس. 
استخدم الباحث طريقة التجزئة النصفية، وكان معامل سبيرمان/ براون، ومعامل جتمان

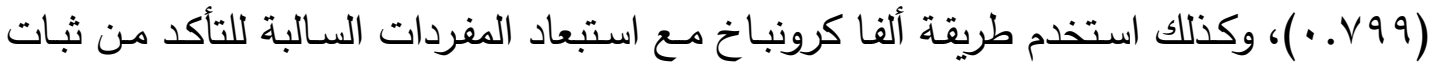
المقياس، وكان معامل ألفا قبل استبعاد المفردات السالبة (99. . .). 


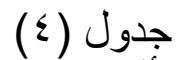

معامل ثبات المقياس باستخدام ألفا كرونباخ مع حذف المفردات السالبة

\begin{tabular}{|c|c|c|c|c|c|c|c|c|c|c|c|}
\hline 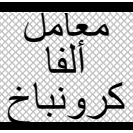 & ألمفرد & 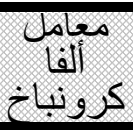 & المفرن & 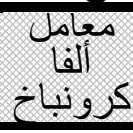 & Ij & 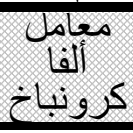 & الميرد & 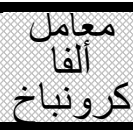 & المبر: & كرونتباخ & أل \\
\hline. .19 & «1 &.$\vee v q$ & זr & $\ldots \vee q$ & ro &.$\vee v q$ & IV & $\therefore \vee q$ & 9 &.$\wedge$. & 1 \\
\hline.$\vee v q$ & $\varepsilon r$ &.$\vee v q$ & $\Gamma \varepsilon$ &.$\wedge$. & Y &.$\vee \wedge \wedge$ & 11 &.$\vee 9$ & 1. & $\cdot . \wedge 1-$ & $r$ \\
\hline.$v 9$ & $\varepsilon r$ &. .19 & ro & $\cdot . \wedge Y-$ & $r V$ &.$\vee v q$ & 19 & $\because \vee q$ & 11 & $\because \vee q$ & $r$ \\
\hline$. . \wedge I-$ & $\leqslant \varepsilon$ &.$v \vee q$ & ד &..$\vee q$ & YA &.$\wedge$. & $r$. & $\because \vee \wedge$ & IT & $\therefore \wedge$. & $\varepsilon$ \\
\hline .A. & $\leqslant 0$ & $\cdot . \wedge \cdot-$ & $r v$ & $\ldots \vee q$ & rq & $\cdot . \wedge 1-$ & YI & $\because \vee q$ & $\pi$ & 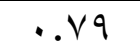 & 0 \\
\hline \multirow[t]{3}{*}{$\cdot . \wedge I-$} & $\sum 7$ & $. \wedge 1-$ & rᄉ & $\therefore \wedge$. & $r$. &.$\wedge$. & Tr &.$\vee v q$ & $1 \varepsilon$ & $\because \vee q$ & 7 \\
\hline & &.$v 9$ & $r q$ &.$v 9$ & ו &.$\wedge$. & זr &.$v 9$ & 10 &.$v q$ & V \\
\hline & & $\because \vee q$ & $\varepsilon$. &.$\vee \vee 9$ & Tr & $\because \vee q$ & $r \varepsilon$ & $\cdot . \wedge 1-$ & 17 &.$v 9$ & $\wedge$ \\
\hline
\end{tabular}

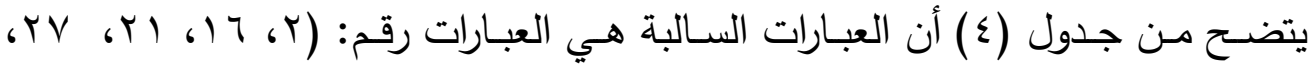
S

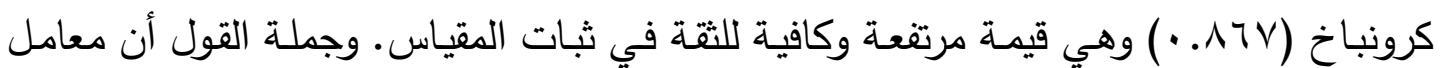

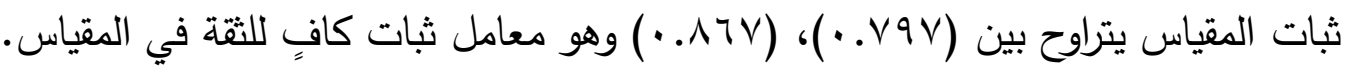

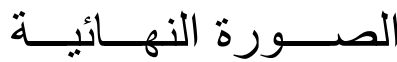

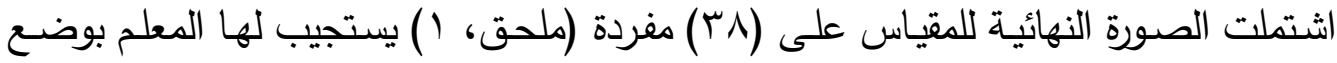

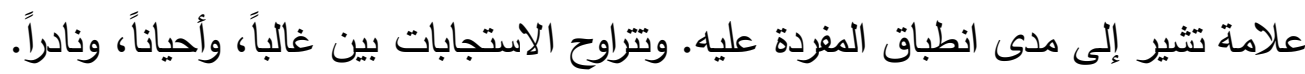

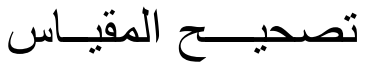

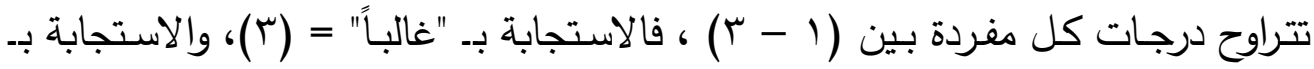

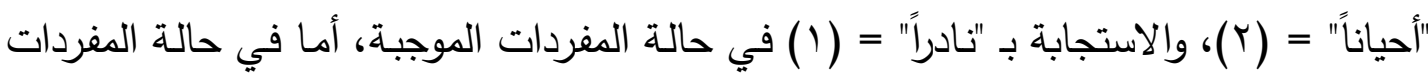

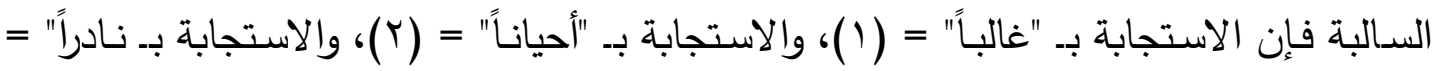

$$
\text { تنــائســ الــدراســـة }
$$

$$
\text { اختبار صحة الفرض الأول }
$$

ينص الفرض الأول على أنها "توجد فروق جوهريـة في نوعية الضـنوط المهنية لمعلمي

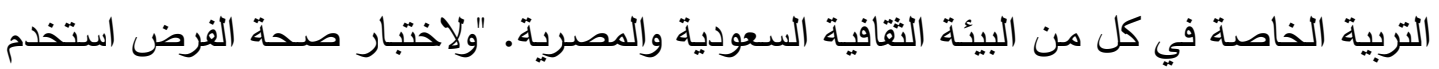

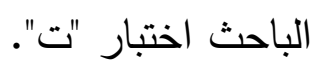

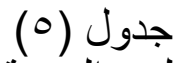
الفروق النو عية في الضغوط المهنية لمعلمي التزبية الخاصة بين البيئة السعودية والمصرية 


\begin{tabular}{|c|c|c|c|c|c|c|c|}
\hline \multicolumn{3}{|c|}{$\because(10=0)$} & \multicolumn{3}{|c|}{ 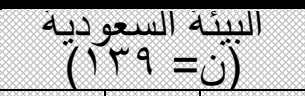 } & \multirow{2}{*}{ 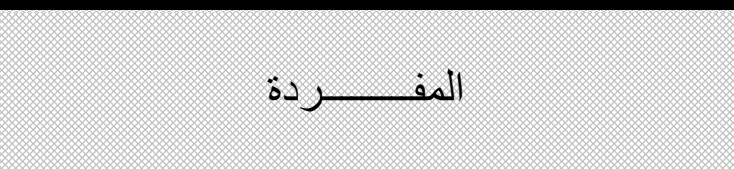 } & \multirow{2}{*}{ ا I } \\
\hline 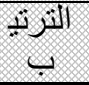 & $\varepsilon$ & $r$ & تئj & $\varepsilon$ & $r s_{1}$ & & \\
\hline 9 & זד, . & $1, \times 1$ & 9 & $?_{7}^{7}$ & $1, \leqslant 0$ & | 1 - أشعر بالرضا عن انضباط التلاميذ. & \multirow{10}{*}{ خصائص الأطفال } \\
\hline r & $\cdot, 7)$ & $r, 17$ & 7 & $\because, \mathrm{V}$ & 1,97 & ع - يزعجني تشتت انتباه التلاميذ. & \\
\hline$\varepsilon$ &., 00 & $r, 10$ & 1 & $a^{2}$ & $r, r$. & 9- يؤسفني إهمال بعض التلاميذ لمظهرهم. & \\
\hline$\wedge$ & $\cdot, 7$ & $1, \wedge 7$ & $\Lambda$ & $\cdot, \mathrm{V}$ & $1, \wedge$. & با للتلاميذ. أعـاني بسـبب صــوبة توصـيل المعلومــات & \\
\hline 1 & . TV & $r, r)$ & $r$ & $i$ & $r, Y \varepsilon$ & |lV - تضايقني سرعة نسيان التلاميذ لما تعلموه. & \\
\hline$r$ & $\cdot, 17$ & $r, 17$ & $\varepsilon$ & $\cdot, 7$ & $r, 1 T$ & 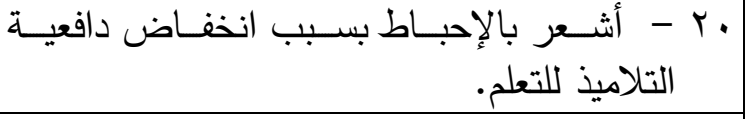 & \\
\hline 7 & $\cdot, V_{0}$ & $r, \cdot V$ & V & $\dddot{7}^{2} \mathrm{~V}$ & 1,91 & ؟ ؟ - يزعجني نشاط التلاميذ الزائد. & \\
\hline V & $\cdot, 7)$ & $r, \ldots$ & 0 & •iv & $r, \ldots$ & للإعاقة - أشـعر بـالتوتر بسـبـ اللزمـات المصـاحبة & \\
\hline \multirow[t]{2}{*}{0} & $\cdot, 0 \wedge$ & $r, 11$ & $r$ & $i^{v}$ & $r, Y)$ & هب - تزعجني المشكلات السلوكية المصاحبة لإعاقة & \\
\hline & 1,94 & $\begin{array}{c}\nabla \Lambda, 1 \\
0\end{array}$ & & $\begin{aligned} T, q \\
\gamma\end{aligned}$ & $\begin{aligned} V, V \\
q\end{aligned}$ & |الدرجة الكلية للبعد ا & \\
\hline$\wedge$ & • & 1,91 & V & 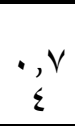 & $1, \wedge \Lambda$ & 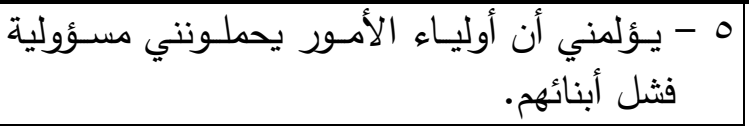 & \multirow{10}{*}{ العأولياء العلاقة الأحور } \\
\hline 7 & $\cdot, V \leqslant$ & $r, \cdot V$ & $r$ & $\cdot \vec{i}$ & $r, r_{1}$ & • أبنائهم في نهـايقني تـأخر أوليـاء الأمسـور فـي اسـتلام & \\
\hline V & $\therefore,{ }_{0}$ & $r, \cdot r$ & $\Lambda$ & $e^{4}$ & $1, \wedge r$ & ع ا - تحزنتي شكاوى أولياء الأمور ضد المعلمين. & \\
\hline 9 & $\cdot, v_{1}$ & 1,7 . & 9 & 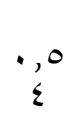 & $1, r \wedge$ & 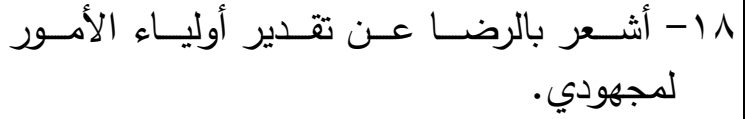 & \\
\hline$\varepsilon$ & $\cdot, 79$ & $r, 17$ & $\varepsilon$ & $e^{4} \mathrm{r}$ & $r, I V$ & | ب - يزعجني عدم فهم أولياء الأمور لدور المعلم. & \\
\hline r & $\cdot, 7 r$ & $Y, Y T$ & 7 & $\because, \mathrm{V}$ & 1,99 & البرامج التدريبية. & \\
\hline 0 & $\cdot, V \mu$ & $r, 1 \leqslant$ & 0 & $\cdot, v$ & $r, \cdot \varepsilon$ & 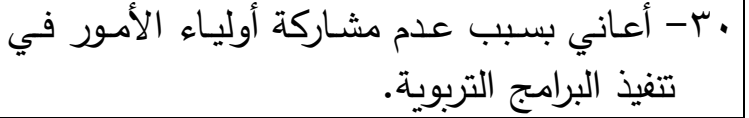 & \\
\hline$r$ & $\cdot, 7)$ & $r, Y V$ & 1 & $e^{i}$ & $r, r q$ & 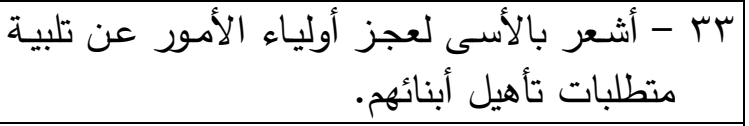 & \\
\hline \multirow[t]{2}{*}{1} & $\cdot, v$. & $r, Y \wedge$ & r & $\because, \mathrm{V}$ & $r, Y \wedge$ & جأ- يزعجني عدم متابعـة أوليـاء الامـور لتحصسيل & \\
\hline & $r, 1 \Gamma$ & $\hat{l}_{r}^{1}, \Lambda$ & & $r, \xi$ & $\frac{11}{1}$ & |الدرجة الكلية للبعد & \\
\hline
\end{tabular}




\begin{tabular}{|c|c|c|c|c|c|c|c|}
\hline \multicolumn{3}{|c|}{$4(10=0)$} & \multicolumn{3}{|c|}{ 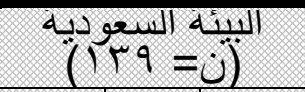 } & \multirow{2}{*}{ i) } & \multirow{2}{*}{ ال:بع } \\
\hline$\ddot{\ddot{i j}+11}$ & $\varepsilon$ & ? & 而 & $\varepsilon$ & 5 & & \\
\hline$\varepsilon$ & $\cdot, 7$. & $r, .0$ & 0 & $\cdot 9$ & $1, \vee \wedge$ & 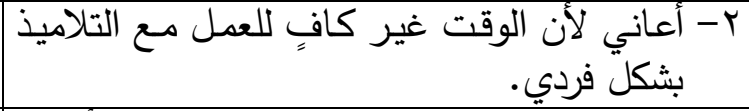 & \multirow{8}{*}{ العمل مع الأطفال } \\
\hline 7 & . & 1,97 & r & $\ddot{v} v$ & $r, 11$ & آ - ترهل تلتي كثرة الخطط التربويـة الفردية التي أعدها & \\
\hline V & $\cdot, V_{1}$ & $1,9 \leq$ & 7 & $i^{v}$ & 1,7 & Y Y - أعاني بسبب كثرة الأعمال الإدارية. & \\
\hline 1 & $\cdot, V \mu$ & $r, Y_{T}$ & r & $\cdot{ }_{0}^{\prime}$ & $r, 1 \leqslant$ & דr- آعاني بسبب الالتزام الروتيني بالمقرر • & \\
\hline 0 & $\cdot, V Y$ & 1,99 & 1 & $i^{v}$ & $r, 17$ & اب- يسيطر عليَّ الملل بسبب قلة الأنشطة الحرة. & \\
\hline$r$ & $\cdot, V \mu$ & $r, . q$ & V & $e_{7}^{2}$ & 1,01 & 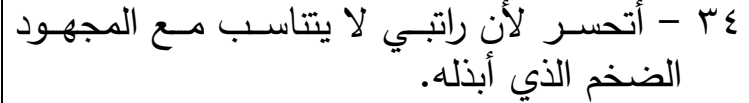 & \\
\hline \multirow[t]{2}{*}{$r$} & $\cdot, v_{1}$ & $Y, Y Y$ & $\varepsilon$ & $i^{i}$ & $r, \cdot V$ & V - يؤرقني عدم حصولي على التذريب الكافي. & \\
\hline & $r, \varepsilon \wedge$ & $\hat{r}^{1}, 0$ & & $i$ & $T^{T}$ & الدرجة الكلية للبعد البعا & \\
\hline$\varepsilon$ & $\cdot, \wedge$. & $r, Y$. & 7 & $\cdot e_{\varepsilon}^{, \Lambda}$ & 1,97 & ب - أشعر بالرضـا لوجود مكان مناسب للاسترخاء & \multirow{9}{*}{ لبئة العمل الأطفال } \\
\hline 1 & $\cdot, 71$ & r & $r$ & $i^{1}$ & $r, Y \leq$ & 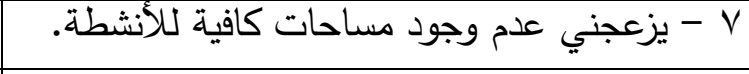 & \\
\hline 0 & $\cdot, \mathrm{V} r$ & $r, r \cdot$ & 0 & $\ddot{i} \wedge$ & $r, \cdot r$ & 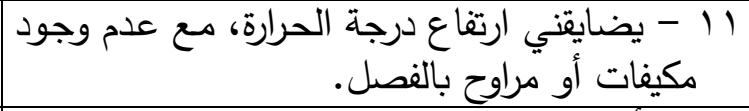 & \\
\hline$r$ & • & $r, Y \leqslant$ & r & $e^{2}, \mathrm{~V}$ & $r, r$. & 10 - أتحسر على عدم توافر المعززات بالمدرسة. & \\
\hline$r$ & $\cdot, \wedge 7$ & $r, Y T$ & $\wedge$ & $\cdot, 7$ & $1, \leqslant Y$ & 19 بأمان - آشعر بالرضـا لوجود مواصـلات تنقل الأطفال & \\
\hline 7 & $\cdot, V \leqslant$ & $r, r$. & 1 & $\cdot \frac{1}{7}$ & $r, \pi$ & با الأطفال. أشـعر بالأسـى لعـدم وجـود تجهيـزات تتاسـب & \\
\hline V & $\cdot, v_{1}$ & $r, .0$ & $\varepsilon$ & $i^{i} v$ & $r, \cdot 9$ & 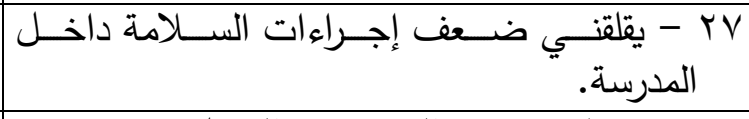 & \\
\hline \multirow[t]{2}{*}{$\Lambda$} & $\cdot, \vee \vee q$ & $1,9 \leq$ & V & $\because v$ & $1, \times 1$ & r T - يضايقني سوء التهوية في الفصل. & \\
\hline & $r, 9 r$ & $1, i, \varepsilon$ & & T, & 19,1 & الدرجة الكلية للبعد البعا & \\
\hline$r$ & $\cdot, \mathrm{V} r$ & $r, \cdot T$ & $\varepsilon$ & $7_{7}^{7}$ & 1,70 & ^ - تحزنني سرعة انفعال زملائي. & \multirow{6}{*}{ العالزملاء } \\
\hline$\varepsilon$ & $\cdot, V \cdot$ & 1,87 & $r$ & $\cdot 9$ & $1, v$. & 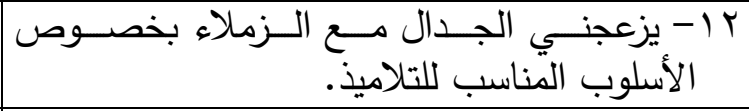 & \\
\hline 1 & $\cdot, V \leqslant$ & $r, \cdot q$ & 1 & ir & $1,9$. & 17 - 17 & \\
\hline$r$ & $\cdot,(x)$ & $1, \wedge \wedge$ & $r$ & ${ }^{4}, 7$ & $1, v$. & 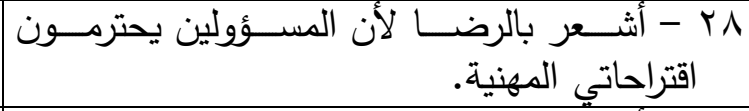 & \\
\hline \multirow[t]{2}{*}{0} & • & 1,09 & 0 & ${ }^{*}{ }^{V}$ & $1,0 \mathrm{r}$ & المدرسة - أشـعر بالرضــا عـن العمل بـروح الفريـق في & \\
\hline & $1, \wedge 1$ & $9, \pi 9$ & & 1,9 & $\Lambda, \leqslant 0$ & الدرجة الكلية للبعد & \\
\hline
\end{tabular}




\begin{tabular}{|c|c|c|c|c|c|c|c|}
\hline \multicolumn{3}{|c|}{ 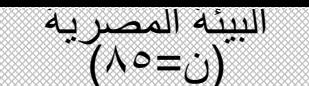 } & \multicolumn{3}{|c|}{ (I } & \multirow{2}{*}{ 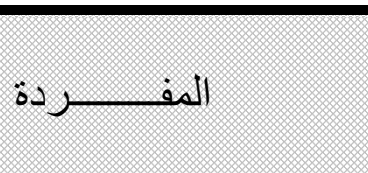 } & \multirow{2}{*}{ البعد البي } \\
\hline ت. & $\varepsilon$ & 5 & التز & $\varepsilon$ & r & & \\
\hline & & & & $\lambda$ & & & \\
\hline & $\Lambda, \vee \diamond$ & 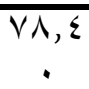 & & $\begin{array}{l}111 \\
71\end{array}$ & $\begin{array}{c}V \varepsilon, \cdot \\
0\end{array}$ & الارجة الكلية للمقياس & \\
\hline
\end{tabular}

تفسير نتائج الفرض الأول

يتضـح من جدول (0) أن معلمي التربية الخاصـة العاملين في البيئة الثقافية السعودية

والعاملين في البيئة الثقافية المصرية يتشـابهون في إدراكهم وتقديرهم لأسباب الضغوط المهنية؛ إذ كان تطابق ترتيبهم لأبعاد المقياس في كلتا البيئتين التقافيتين: فقد كان "خصائص الأطفال ذوي الاحتياجـات الخاصـة" في المرتبـة الأولى في استثارة شعور المعلمين بالضـغوط المهنيـة، ويليـه بعد "العلاقـة بأولياء أمور الأطفال ذوي الاحتياجـات الخاصـة"، ثم بعد "بيئة العمل مـع الأطفال ذوي الاحتياجات الخاصة"، فبعد "طبيعة العدل مع الأطفال ذوي الاحتياجات الخاصـة" وفي النهايـة بعد "العلاقة المهنيـة بالزملاء والمدراء"، والذي كان أقل الأبعاد كسبب للضـغوط المهنية لمعلمي التربية الخاصـة. ويرى الباحث أن ذلك ربما يرجع إلى التقارب والتشابه الكبير في البيئة الثقافيـة السعودية والمصرية، لاسيما في النظم التعليمة فيهما، وخصوصـاً نظم إعداد المعلمين بشكل عام ومعلمي التربية الخاصة بشكل خاص. وقد يرجع ذلك أيضاً إلى أن خصائص الأطفال ذوي الاحتياجات الخاصة واحتياجاتهم الفريدة تلقي بأعباء إضافية على كاهل معلميهج؛ فغالباً ما تصاحب الإعاقة سمات وخصائص تزيد من صدعوبة التعامل مـع أصـابها. فذذو الإعاقة العقلية يعانون من ضـف القدرة على الانتباه، والتذكر ، والتعلم، والتعميم ونقل أثر التعلم. كما يعانون من قصور في النمو اللغوي والاجتماعي، ومن ضعف القدرة على ضبط الذات، وضعف الثقة في أنفسهم، وينخرط بعضهم

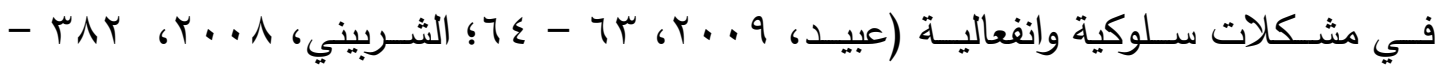
بو ب). وهي كلها خصـائص وسـمات تؤثر سـلباً على العمليـة التعليميـة وتلقي بظلالها على المعلم وتضيف ضـوطاً على الضغوط التي يتعرض لها. وليس التوحديون بأحسن حالاً، بل ربما تضاف للخصائص السـابقة صسوبة التواصل معهم إذ يفشلون في التواصل اللفظي وغير اللفظي، ويفتقرون للتواصل الاجتماعي، وينخرطون في السلوكيات النمطية، ويتسمون بأنماط 
جامدة ومحددة من التركيز تتحصر في موضوعات أو أشياء محددة، ويقاومون أدنى تغيير على نمط حياتهم أو على البيئة الدحيطة بهم. كما يعانون من قصور في الإدراك، والانتباه، وتكوين المفاهيم، وحل المشكلات. وكذلك يعانون من اضطرابات نفسية تثمل الاكتئاب، والوساوس

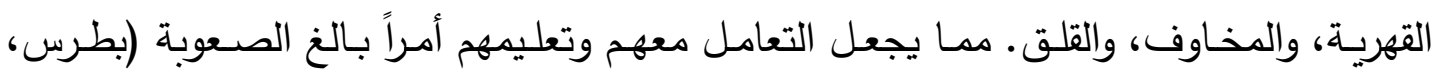

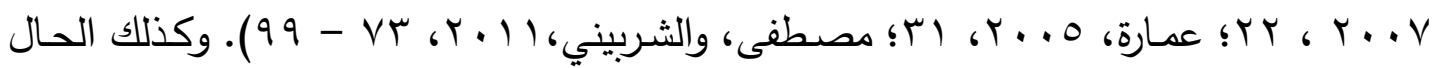
بالنسبة لذوي الإعاقة البصرية إذ يعانون من مفهوم ذات سلبي، ومن قصور في تفاعلاتهم

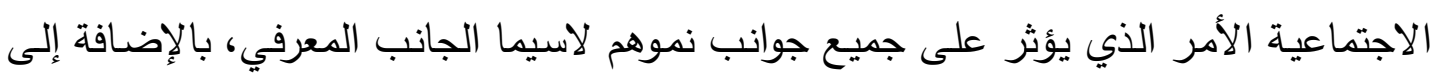

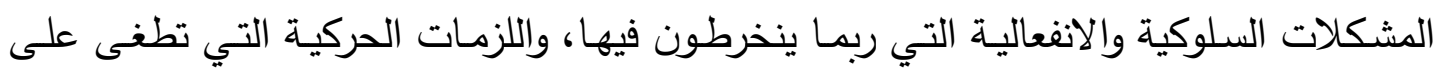

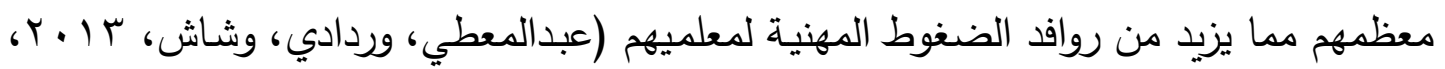

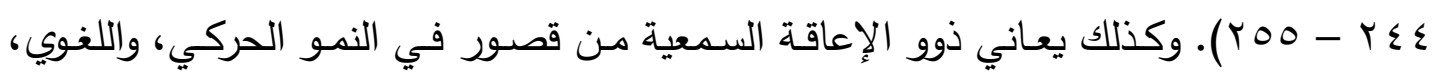

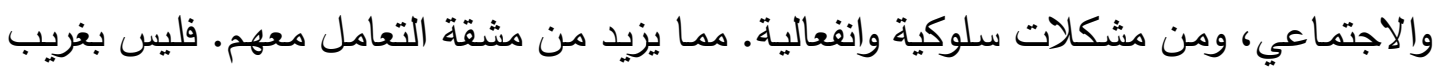

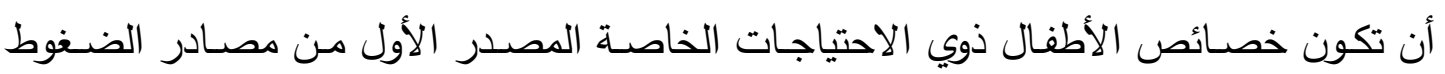
المهنية لمعلمي التربية الخاصة في البيئة السعودية والمصرية على حدٍ سواء...

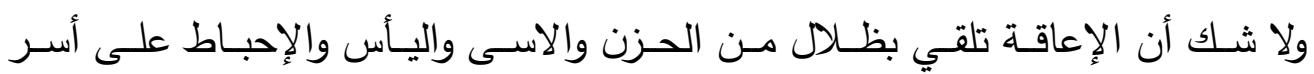
الأطفال، وعلى أولياء أمورهم، وفي بعض الحالات تؤثر تلك المشاعر السلبية على تفاعلاتهم مـ كل من يتعامل معهم، وأولهم معلمي أطفالهم، بل إن بعضهمه قد يلجأ إلى بعض الحيل

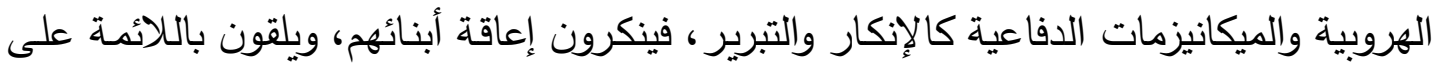

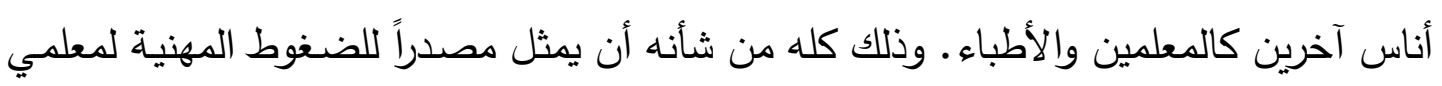

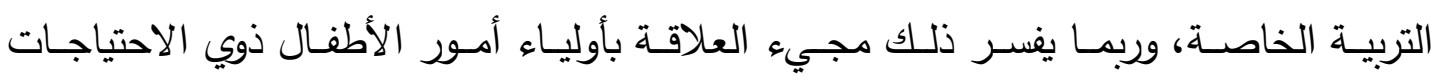

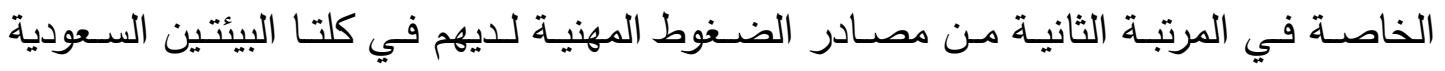

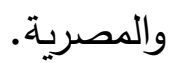
ولكن اختلف ترتيب مفردات المقياس حسب درجة الضغوط من البيئة السعودية إلى

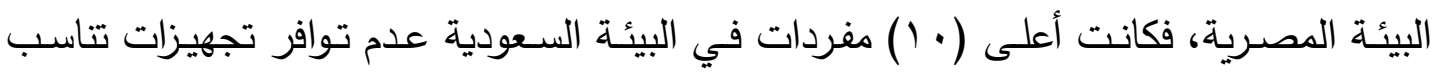

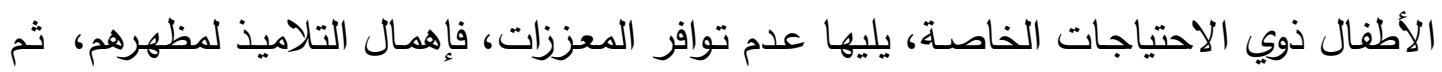
عجز أولياء الأمور عن تلبية متطلبات تأهيل أبنائهم، ثم عدم متابعة أولياء الأمور لتحصيل 
أبنائهم، فسرعة نسيان التلاميذ لما تعلموه، ثم عدم وجود مساحات كافية للأنشطة، ثم المشكلات السلوكية المصـاحبة للإعاقة، فتأخر أولياء الأمور في استلام أبنائهج في نهاية العمل، وأخيراً عدم فهم أولياء الأمور لدور المعلم. بينما كانت أعلى (• (1) مفردات في البيئة المصرية عدم وجود مسـاحات كافيـة للأنشطة، وعدم متابعـة أوليـاء الأمـور لتحصيل أبنائهج، وعجز أولياء الأمور عن تلبية متطلبات تأهيل أبنائهم، ثم عدم التزام أولياء الأمور بحضور البرامج التدربيية، فالالتزام الروتيني بالمقرر، فعدم وجود مواصـلات تتقل الأطفال بأمان، ثم عدم توافر المعززات، ويليه عدم حصول المعلم على التدريب الكافي، فسرعة نسيان التلاميذ لما تعلموه، وأخيراً عدم وجود تجهيزات تتاسب الأطفال ذوي الاحتياجات الخاصة. واختلف ترتيب المفردات داخل كل بعد في البيئة السعودية عنه في البيئة المصرية ففي البعد الأول المتعلق بخصـائص الأطفـال ذوي الاحتياجـات الخاصـة كـان إهــال التلاميذ لمظهرهم أول مصـادر الضغوط في البيئة السعودية، يليه سرعة نسيان التلاميذ لما تعلموه، ثم مشكلات الأطفال السلوكية، ثم انخفاض دافعية التلاميذ، ثم اللزمات المصاحبة للإعاقة، فتشتت انتباه التلاميذ، ونشاطهم الزائد، واحتلت صعوبة توصيل المعلومات للتلاميذ المرتبة قبل الأخيرة في حين جاء عدم انضباط التلاميذ في المرتبة الأخيرة كمصدر للضغوط المهنية. في حين كان نسيان التلاميذ لما تعلموه في المرتبة الأولى كمصدر للضغوط المهنية لمعلمي التربية الخاصـة في البيئة المصـرية، ويليـه تشـت انتبـاه التلاميذ، وانخفـاض دافعيتهم، ثم إهمـالهم لمظهرهم، فمشكلاتهم السـلوكية، ونشـاطهم الزائد، ولزمـات إعاقتهم، ثم صـعوبة توصيل المعلومـة، وأخيراً عدم انضباطهم والذي شغل المرتبة الأخيرة في كلا البيئتين السعودية والمصرية. وكذلك اختلف معلمو التربية الخاصة في البيئة الثقافية السعودية عنهم في البيئة الثقافية المصـرية في ترتيب مفـردات البعـد الثـاني المتمثل فـي العلاقـة بأوليـاء أمـور الأطفـال ذوي الاحتياجات الخاصـة كأسباب للضـغوط المهنية. فكان عجز أولياء الأمور عن تلبية متطلبات تأهيل الأطفال في المرتبة الأولى في كمصدر للضغوط في البيئة السعودية، يليه عدم متابعـة تحصيل الأطفال، فتأخرهم في استلام الأطفال في نهاية العمل، ثم عدم فههم لدور المعلم، ثم عدم مشاركتهم في تتفيذ البرامج التربوية، ثم عدم حضورهم البرامج التدريبة، ويلي ذلك تحميلهم المعلم مسؤولية فشل أبنائهج، وجاءت شكاواهم ضد المعلمين في المرتبة قبل الأخيرة، وجاء عدم 
تقديرهم لمجهود المعلم في المرتبـة الأخيرة كمصدر للضـغوط المهنيـة. بينما كان عدم متابعة أولياء الأمور لتحصيل الأطفال في المرتبـة الأولى كمصدر للضـغوط المهنية لمعلمي التربية

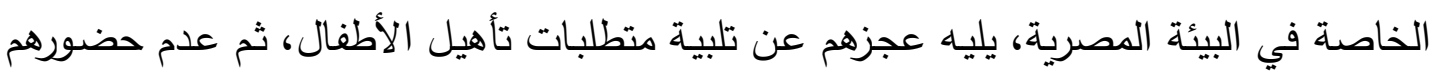
البرامج التدريبية، فعدم فهمهم لدور المعلم، ثم عدم مشاركتهم في تتفيذ البرامج التربوية، يلي

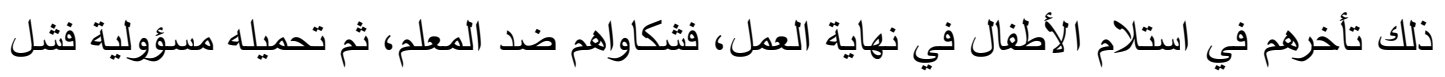

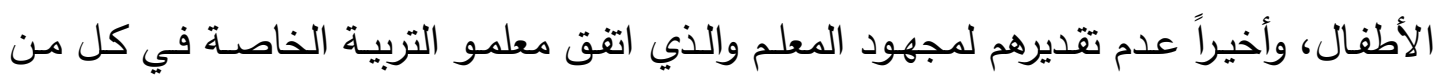
البيئة السعودية والمصرية على ترتيبه كآخر مصدر للضغوط المهنية لديهم.

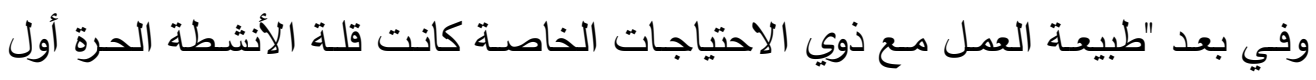

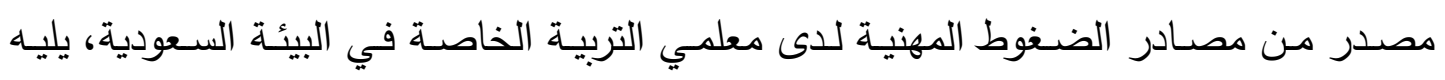

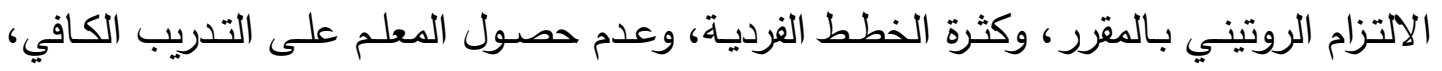

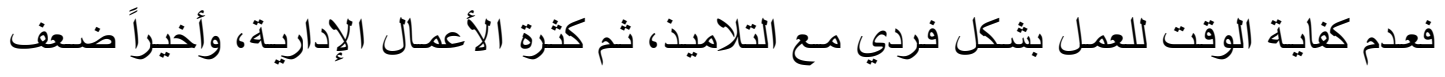
الراتب وعدم اتساقه مع مجهود المعلم. في حين رتب معلمو التربية الخاصة في البيئة الثقافية

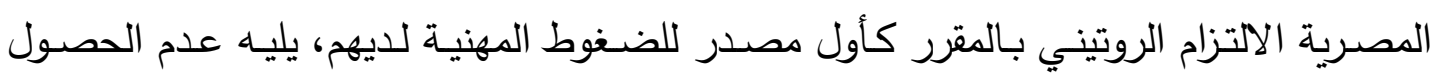

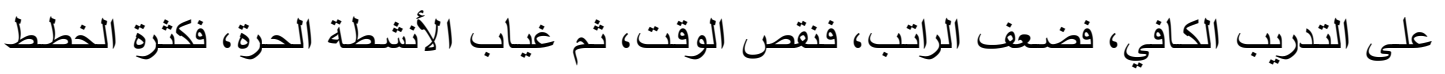

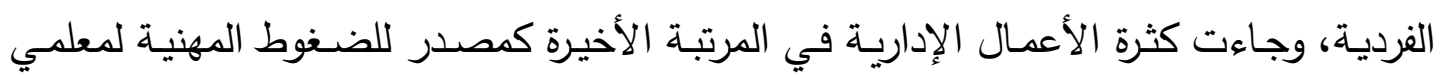
التربية الخاصة في البيئة المصرية. وفي بعد "بيئة العمل" كان عدم توافر التجهيزات المناسبة للأطفال ذوي الاحتياجات

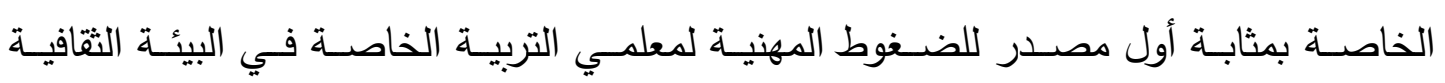

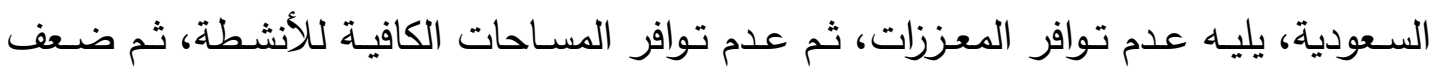

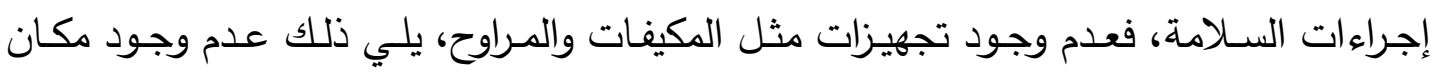
للاسترخاء في وقت الراحة، ثم سوء تهوية الفصل، وأخيراً عدم وجود مواصلات تتقل الأطفال.

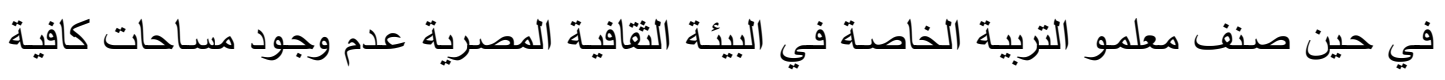
للأنشطة كأول مصدر لضغوطهم المهنية، يليه عدم وجود مواصلات لنقل الأطفال، فعدم توافر

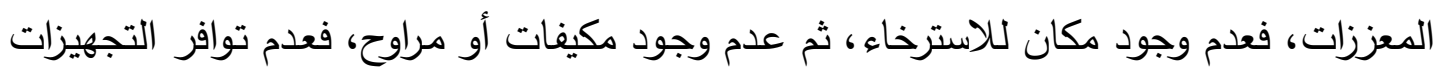

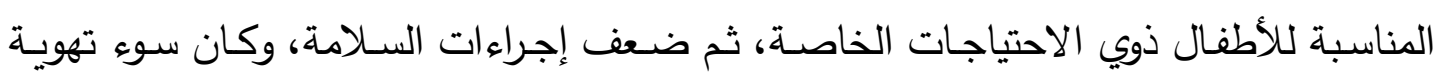
الفصل آخر مصدر من مصادر الضغوط المهنية لمعلمي التربية الخاصة في البيئة المصرية. 
وفي بعـد "العلاقـة المهنيـة بـالزملاء والمـدراء" اتفق معلمو التربيـة الخاصـة في البيئة الثقافية السعودية والمصرية على ترتيب تعارض التوجيهات كأول مصدر لضـغوطهم المهنية، وترتيب غياب العمل بروح الفريق كآخر مصدر لضنوطهم المهنية، وكذلك اتفقوا على وضـع احترام المسؤولين لاقتراحاتهم المهنية في المرتبـة الثالثة. ولكنهم اختلفوا في ترتيب الجدال مـع زملائهم بخصوص الأسلوب المناسب للأطفال؛ إذ جاء في المرتبـة الثانيـة كمصدر للضـغوط المهنية في البيئة السعودية بينما حل في المرتبة قبل الأخيرة في البيئة المصرية، كذلك اختلفوا بخصوص سرعة انفعال الزملاء التي حلت في المرتبـة قبل الأخيرة في البيئة السـودية بينما حلت في المرتبة الثانية في البيئة المصرية. Antoniou, اتققت هذه النتيجة مس نتائج دراسـة أنطونيو، ووبوليكروني، وفلاتشاكيس التي أشارت إلى أن أهم مصادر الضغوط المهنية تمثلت في مشكلات التفاعل مـع الطـلاب ذوي الاحتياجات الخاصـة. واختلفت هذه النتيجة مـع نتائج دراسة شايمان (2009) Shyman التي أشارت إلى أن صراع الدور كان من أهم مصادر الضغوط، ودراسـة بـلاش، وبايوتروسكي(2006) Plash \& Piotrowski التي أثـارت نتائجها إلى أن ظروف العمل كانت أهم مصادر الضغوط، ودراسة جرستن، كيتنج، يوفانوف، وهارنيس Gersten, Keating, Yovanoff, \& Harniss (2001) التـدريس لـذوي الاحتياجـات الخاصـة هـي أهـم مصـادر الضـغوط المهنيـة. وربمـا يرجـع ذلكك الاختلاف إلى التباين بين ظرف البيئات التي أجربت فيها تلك الدراسات وظروف البيئة العربية التي أجريت فيها الدراسة الحالية.

$$
\text { اختبار صحة الفرض الثاني }
$$

ينص الفرض الثاني على أنه "توجد فروق في الضنغوط المهنية لمعلهي التربية الخاصـة تعزى لاختلاف البيئة الثقافيـة التي يعمل فيها المعلم، وفئة الإعاقـة التي يعمل معها المعلم لصالح البيئة الثقافية المصرية ولصالح فئة الإعاقة السمعية."

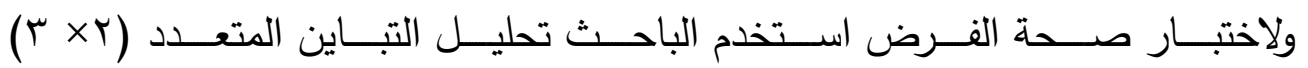
PANOVA واختبار شيفيه Scheffe للمقارنـات البعديـة. وقد أظهر اختبار بيلاي Pillai، 
ويكس Wilks، وهوتيلينج Hotelling، وروي Roy، وجود فروق دالة إحصائياً عند مستوى

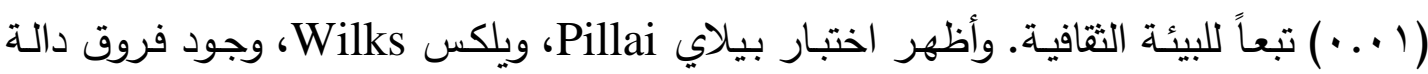

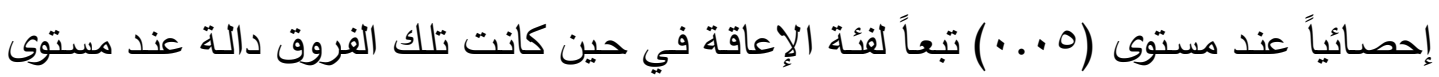
Hotelling بينما لـم تظهر تلك الاختبارات أي فروق دالـة إحصائياً تبعاً للتفاعل بين البيئة الثقافية وفئة الإعاقة. جدول (T) تحليل التباين Y Y Y لدرجات الضغوط المهنية لمعلمي التربية الخاصة تبعاً للبيئة الثقافية وفئة الإعاقة

\begin{tabular}{|c|c|c|c|c|c|c|}
\hline إنينابع & $\underbrace{3}_{3}$ & المربعات & الحرباتي & 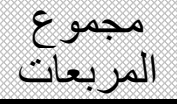 & 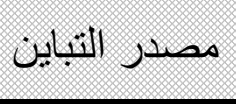 & 1.11 \\
\hline$\cdots \varepsilon$ & $* * q$. . r & $909 . \leqslant \leqslant$ & 1 & $909 . \leqslant \leqslant$ & البيئة الثقافية & \multirow{3}{*}{ الدرجة الكلية } \\
\hline \multirow[t]{3}{*}{$\cdots v$} & **A.r & AVT.VT & r & $1 V \leqslant V . \leqslant 0$ & فئة الإعاقة & \\
\hline & r.09 & TVE. $7 \leq$ & r & $0 \leqslant 9.19$ & التفاعل & \\
\hline & س.ו. & 19.97 & 1 & 19.97 & البيئة الثقافية & \multirow{3}{*}{ خصائص الأطفال } \\
\hline \multirow[t]{3}{*}{$\cdots v$} & $* * \wedge .01$ & $0 \leqslant . Y T$ & r & $1.1 .0 r$ & فئة الإعاقة & \\
\hline & Y.AY. $\leqslant 0$ & $1 V .9 V$ & r & ro. $\leqslant \varepsilon$ & التفاعل & \\
\hline & .11 & 1.199 & 1 & 1.199 & البيئة الثقافية & \multirow{3}{*}{ أعور الأطلاقة بأولياء } \\
\hline \multirow[t]{2}{*}{$\cdots r$} & $*$ *.. 9 & qu.rq & r & 77.199 & فئة الإعاقة & \\
\hline & r.91 & 51.91 & r & 74.94 & التفاعل & \\
\hline$\cdots \varepsilon$ & $* * q . . r$ & OV.Vo & 1 & ov.vo & البيئة الثقافية & \multirow{3}{*}{ طبيعة العمل مع } \\
\hline \multirow[t]{2}{*}{$\cdots 1$} & $* * 9.1 \leq$ & 01.04 & r & $11 \mathrm{~V} . . \mathrm{V}$ & فئة الإعاقة & \\
\hline & 1.10 & $11.1 \mathrm{~V}$ & r & $r T . V \varepsilon$ & التفاعل & \\
\hline. .0 & $\begin{array}{c}* 11 . . V \\
*\end{array}$ & 1.1 .19 & 1 & 1.1 .19 & البيئة الثقافية & \multirow{3}{*}{ بيئة العمل } \\
\hline \multirow[t]{2}{*}{$\cdot . r$} & $* T . \Sigma Y$ & T & r & 77.91 & فئة الإعاقة & \\
\hline & .990 & 9.11 & r & 11.74 & التفاعل & \\
\hline \multirow[t]{3}{*}{$\cdots 7$} & $\begin{array}{c}* 10 . r 0 \\
*\end{array}$ & OV.TV & 1 & OV.rV & البيئة الثقافية & \multirow{3}{*}{ العلاقة بالزملاء } \\
\hline & $r . . r$ & $\mathrm{~V} .0 \mathrm{~V}$ & $r$ & 10.11 & فئة الإعاقة & \\
\hline & -.99 & $r . v 1$ & r & $V . \leqslant Y$ & التفاعل & \\
\hline
\end{tabular}




$$
\begin{aligned}
& \text { ** دالة عند مستوى (1 (..)، * دالة عند مستوى (0...) }
\end{aligned}
$$

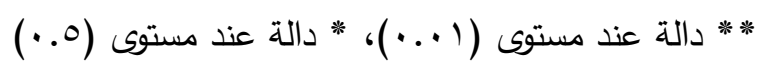




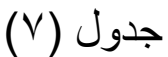

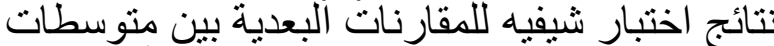

درجات الضغوط المهنية لمعلمي التربة الخاصة تبعاً لمتغير فئة الإعاقة

\begin{tabular}{|c|c|c|c|c|c|c|c|c|c|}
\hline \multicolumn{3}{|c|}{ 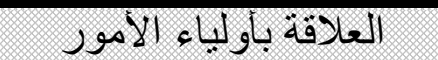 } & \multirow[t]{2}{*}{ الفنة } & \multirow[t]{2}{*}{ البعد } & \multicolumn{3}{|c|}{ Jlib إ un } & \multirow[t]{2}{*}{ الفنة } & \multirow[t]{2}{*}{ 1إ } \\
\hline ixum & بي & ونولئن & & & inew & ب & وتونئ: & & \\
\hline${ }^{*} 1,0 Y_{-}$ & $\cdot, 17$ & - & عقلية وتوحد & \multirow{3}{*}{ الألمولياء } & $0, Y O_{-}$ & $* * 1, \leqslant 0$ & - & وتوحلية & \multirow[t]{3}{*}{ خصائص الأطفال } \\
\hline $1,7 \wedge$ & - & & بصرية & & $*{ }_{* *}^{-}, 9 \wedge$ & - & & بصرية & \\
\hline - & & & سمعية & & - & & & سمعية & \\
\hline \multicolumn{3}{|c|}{ الدرجة الكلية } & الفئة & البعد & \multicolumn{3}{|c|}{ طبيعة العمل } & الفئة & \multirow{2}{*}{ البعد } \\
\hline سمعية & بصرية & عقلية وتوحد & & & سمعية & بصرية & عقلية وتوحد & & \\
\hline$\varepsilon, r \cdot-$ & $\varepsilon, r)$ & - & عقلية وتوحد & \multirow[t]{3}{*}{ الكلية } & $\cdot, 91-$ & $* 1, r \leqslant$ & - & وتوحلية & \multirow[t]{3}{*}{ طبيعة } \\
\hline $\begin{array}{c}- \\
* \Lambda, \leqslant 1 \\
*\end{array}$ & - & & بصرية & & $* * r, 10$ & - & & بصرية & \\
\hline - & & & سمعية & & - & & & سمعية & \\
\hline
\end{tabular}

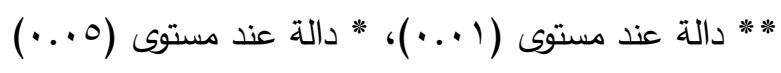

يتضـح من جدول (T)، (V) وجود فروق دالـة إحصـائياً في الدرجـة الكلية على مقيـاس

الضغوط المهنية لمعلمي التربية الخاصة تعزى لمتغيري البيئة الثقافية التي يعمل فيها المعلم وفئة الإعاقة التي يعمل معها، في حين لم توجد فروق دالة في التفاعل بينهما. إذ وجدت فروق دالة إحصائياً في الدرجة الكلية للمقياس وفي أبعاد "خصائص الأطفال ذوي الاحتياجات الخاصـة"، و"العلاقـة بأوليـاء أمسور الأطفال ذوي الاحتياجـات الخاصـة"، و"طبيعـة العمل مـع الأطفال ذوي الاحتياجات الخاصة" لصالح العاملين مع فئة الإعاقة السمعية. وهذه النتيجة في مجملها تحقق Russell, \& Wiley صحة الفرض الثاني. وتختلف هذه النتيجة مع نتائج دراسة راسل، وويلي

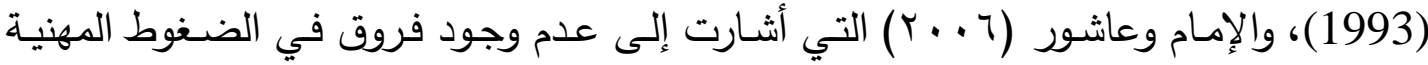
لمعلمي التربيـة الخاصـة تعزى لمتغير فئة الإعاقة التي يعمل معها المعلم؛ وربمـا يفسر ذلك الاختلاف باختلاف البيئة التي أجريت فيها الدراسة الحالية عن بيئة هاتين الدراستين إذ اقتصرت

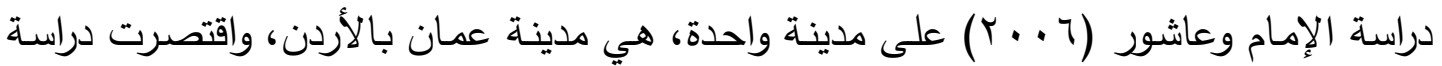
راسل، وويلي (1993) عussell, \& Wiley على بعض المناطق الريفيـة؛ في حين أجريت 
الدراسة الحالية في أكثر من مدينة في السعودية ومصر، وربما يرجع أيضاً إلى الفارق الكبير في

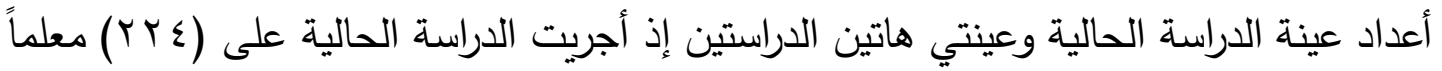

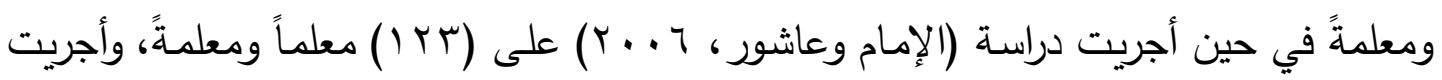

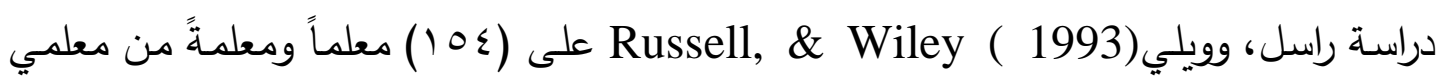
التربية الخاصة.

ويمكن تفسير تلك النتائج بالصـوبات والمشـاق الإضـافية الناتجـة عن العهل مـع فئسة

الإعاقة السمعية على وجه الخصوص. إذ يحتاج العمل مع أفراد هذه الفئة إلى صبر جميل، وجهد دؤوب، وفهم عميق لخصائصـهم، واستخدام طـرق خاصـة في التواصل معهم. لأنهم يعانون من قصور في النمو اللغوي يتجلى في تأخر النمو اللغوي، واضطرابات النطق وضعف الحصيلة اللغوية، ويعانون من قصور في النمو الجسمي والحركي، وضعف التآزر الحركي. وكذلك يعانون من التأخر القرائي، والتأخر التحصيلي العام. كما يعانون من سوء التوافق، ومن لـن

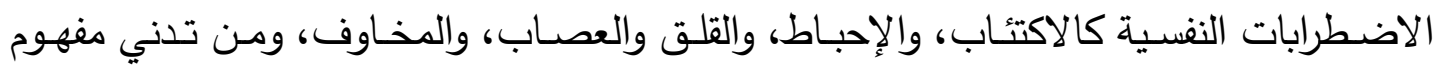
الذات، ومسن نوبات الغضب والعدوان. وكذلك يعانون من قصسور النمو الاجتمـاعي، ونقص

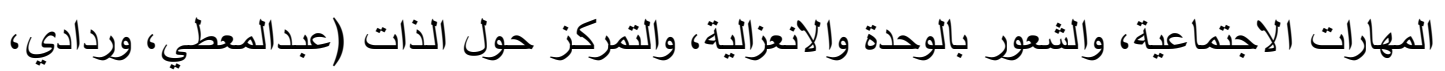

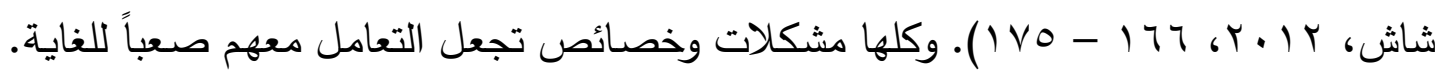
ولذا فإن الضـغوط المهنيـة الملقاة على كاهل معلميهم ربمـا تتضـاعف وتزداد آثارهـا السلبية عليهم. اختبار صحة الفرض الثالث ينص الفرض الثالث على أنه "توجد فروق في الضغوط المهنية لمعلمي التربية الخاصة

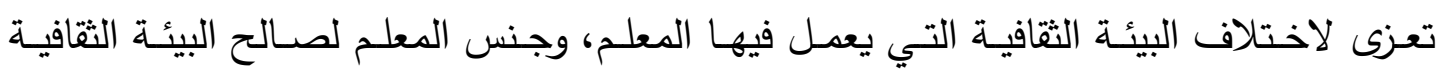

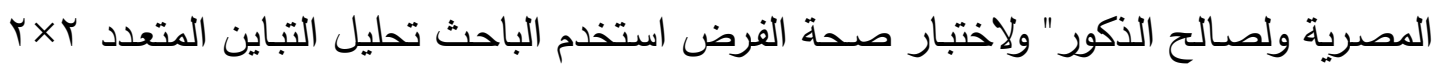

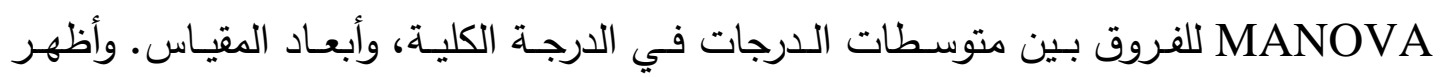
اختبار بيلاي Pillai، ويلكس Wilks، وهوتيلينج Hotelling، وروي Roy، وجود فروق دالة 
إحصائياً عند مستوى (0 . • ) تبعاً لكل من متغيري البيئة الثقافية وجنس المعلم. بينما لم تظهر تلك الاختبارات فروقاً دالة إحصائياً تبعاً للتفاعل بينهما.

\section{جدول (^) (^)}

تحليل التباين Y Y Y لدرجات الضغوط المهنية لمعلمي التربية الخاصة تبعاً للبيئة الثقافية

\begin{tabular}{|c|c|c|c|c|c|c|}
\hline إيتا & : & 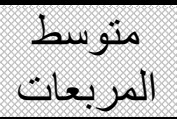 & الحربة & 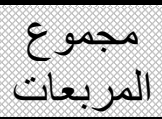 & هيدر التباين & البعت \\
\hline \multirow[t]{9}{*}{$\ldots r$} & ** & $79 \vee . \wedge \wedge$ & 1 & $79 \vee . \wedge \wedge$ & البيئة الثقافية & \multirow{3}{*}{ الدرجة الكلية } \\
\hline &. .14 & $1 T .07$ & 1 & 11.07 & جنس المعلم & \\
\hline & r.. I & r rA.Ir & 1 & r YA.I & |التفاعل & \\
\hline & $1.9 \varepsilon$ & IT.YT & 1 & IT.YT & البيئة الثقافية & \multirow{3}{*}{ 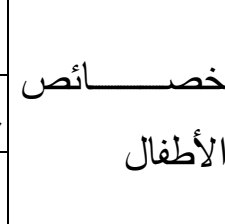 } \\
\hline & $r . \wedge q$ & 19.人 & 1 & 19.14 & جنس المعلم & \\
\hline & $\cdots \varepsilon$ & 7.79 & 1 & $r .79$ & |التفاعل & \\
\hline & r.Ir & ד.r & 1 & ro.r & البيئة الثقافية & \multirow{3}{*}{ أمور الأطفال بأولياء } \\
\hline & $1.1 \mathrm{~V}$ & IT.YT & 1 & IT.KY & جنس المعلم & \\
\hline & $\cdots \varepsilon$ &..$\leqslant q$ & 1 &..$\leqslant q$ & |التفاعل & \\
\hline \multirow[t]{4}{*}{$\ldots r$} & $* * 7.1$. & $\{Y .17$ & 1 & $\{Y .17$ & البيئة الثقافية & \multirow{3}{*}{ طبيعــة العمـل } \\
\hline & $\cdot . \cdot r$ &. .1 & 1 & .1 . & جنس المعلم & \\
\hline & 1.14 & $\vee . \vee q$ & 1 & $v . v q$ & |التفاعل & \\
\hline & Y.A. & $r 7.79$ & 1 & r...79 & |البيئة الثقافية & \multirow{3}{*}{ بيئة العمل } \\
\hline..$r$ & $* \varepsilon .99$ & $\varepsilon \vee .01$ & 1 & $\varepsilon \vee .01$ & جنس المعلم & \\
\hline$\cdot . r$ & $* 0.7$ & or. $\leqslant 7$ & 1 & or. $\leqslant 7$ & |التفاعل & \\
\hline \multirow[t]{3}{*}{$\cdots \varepsilon$} & $* * q . . r$ & rr.Aq & 1 & rr.Aq & |البيئة الثقافية & \multirow{3}{*}{ 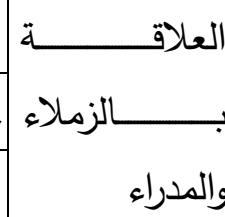 } \\
\hline &..$\leqslant \wedge$ & $1 . \vee \wedge$ & 1 & $1 . \vee \wedge$ & جنس المعلم & \\
\hline & Y.Vq & $1 . . \leqslant V$ & 1 & $1 . . \leqslant V$ & |التفاعل & \\
\hline
\end{tabular}

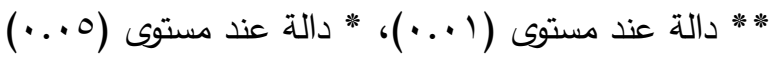

** دالة عند مستوى (1 ...)، * دالة عند مستوى (0. (•) 
يتضـح من جدول (^) وجود فروق دالة إحصائياً في الضغوط المهنية لمعلمي التربية الخاصـة تعزى لمتغير البيئة الثقافية في الدرجة الكلية وفي بعدي "طبيعة العمل مـع الأطفال ذوي الاحتياجـات الخاصـة" و"العلاقـة المهنيـة بـالزملاء والمـدراء" لصـالح العـاملين في البيئـة المصرية في الدرجة الكلية للمقياس، وعدم وجود فروق دالة إحصائياً تعزى لمتغير جنس المعلم

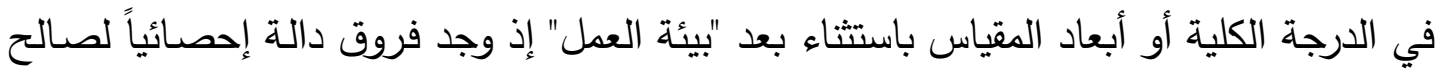

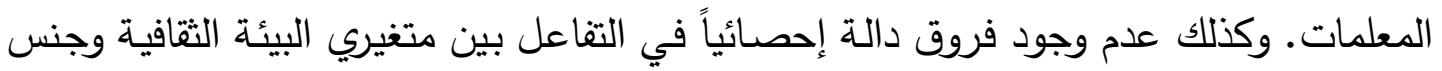
المعلم في الدرجة الكلية أو أبعاد المقياس باستثناء بعد "بيئة العمل" وند

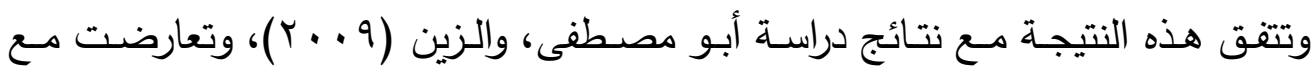

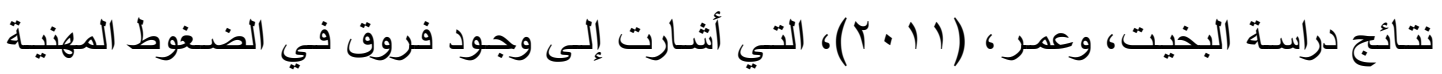
لصالح المعلمين. وربما يرجع ذلك التعارض إلى الاختلاف في العينة؛ إذ بلخ عددها في دراسة

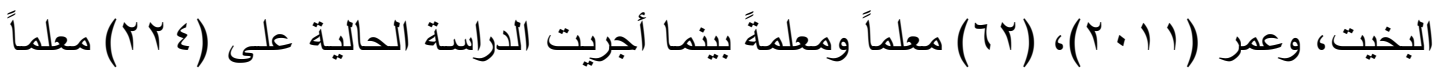

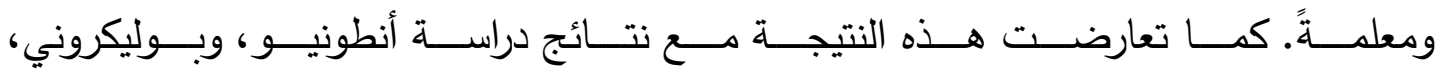
وفلاتثاكيس(Antoniou, Polychroni, \& Vlachakis ) 2006، ودراسة مينر ، ولييتش، التي أشارت إلى وجود فروق دالة إحصائياً لصالح المعلمات، وربما يرجع هذا التعارض إلى الاختلاف في العينة التي تمثلت في المعلين الذين يتعاملون

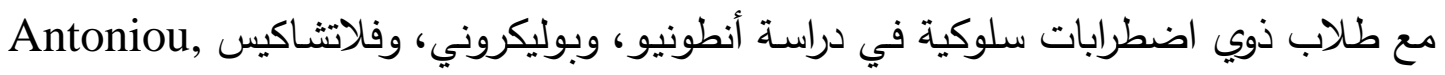

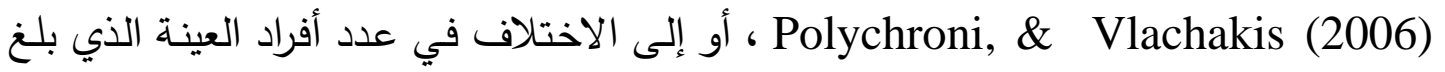

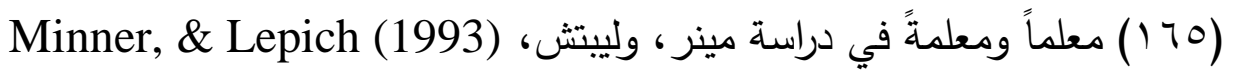
اختبار صحة الفرض الرابع ينص الفرض الرابع على أنه " توجد فروق في الضغوط المهنية لمعلمي التربية الخاصة تعزى لاختلاف البيئة الثقافية التي يعمل فيها المعلم، وسنوات خبرة المعلم لصالح البيئة الثقافية

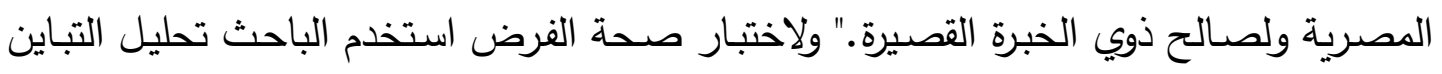

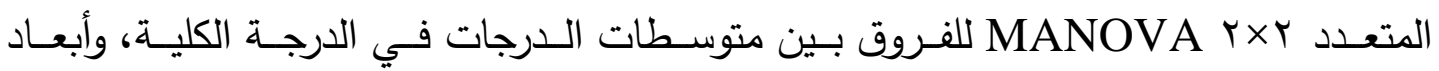

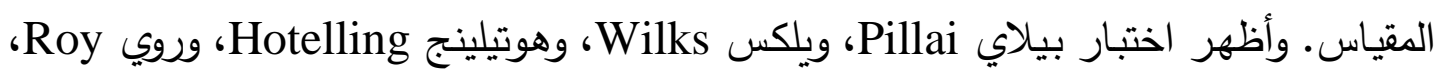




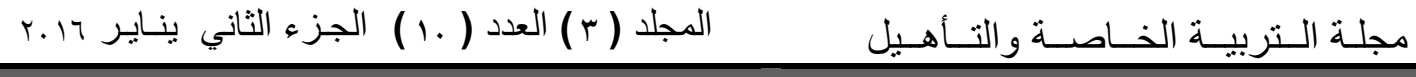

وجود فروق دالة إحصائياً عند مستوى (1 ...) تبعاً لمتغير البيئة الثقافية، بينما لم تظهر تلك الاختبارات فروقاً دالة إحصائياً تبعاً لخبرة المعلم. 


\section{جدول (9) (9) (9)}

تحليل التباين Y Y Y لدرجات الضغوط المهنية لمعلمي التربية الخاصة تبعاً للبيئة الثقافية وخبرة المعلم

\begin{tabular}{|c|c|c|c|c|c|c|}
\hline (بر) & ;: & 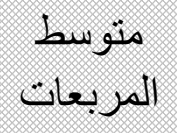 & الدربان & 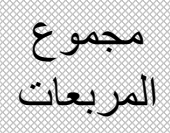 & هيدار التباين & I. \\
\hline \multirow[t]{6}{*}{$\cdot \ldots \varepsilon$} & *q.Ar & $1117.8 \leq$ & 1 & $1117.8 \leq$ & البيئة الثقافية & \multirow{3}{*}{ لالدرجة الكلية } \\
\hline & r... & rYq.97 & 1 & rrq.97 & خبرة المعلم & \\
\hline &. $.9 V$ & 1.9 .97 & 1 & 1.9 .97 & التفاعل & \\
\hline & T.乏I & 17.71 & 1 & 17.71 & البيئة الثقافية & \multirow{3}{*}{ خصـــــائص |لأطفال } \\
\hline & דצ & Y.O. & 1 & Y.O. & خبرة المعلم & \\
\hline & $1 . \wedge \varepsilon$ & IY.TE & 1 & IY.TE & التفاعل & \\
\hline \multirow[t]{3}{*}{$\cdot . r$} & $* \varepsilon .0 \leqslant$ & $01 . Y_{7}$ & 1 & $01 . Y_{7}$ & البيئة الثقافية & \multirow{3}{*}{ لعلاقـــــاء } \\
\hline &..$\leqslant 9$ & $0.0 \mathrm{~V}$ & 1 & $0.0 \mathrm{~V}$ & خبرة المعلم & \\
\hline & 1.17 & $r) . . r$ & 1 & $r) . . r$ & التفاعل & \\
\hline$\cdot .7$ & $* * 1 \leq .9 \Gamma$ & 99.99 & 1 & 99.99 & البيئة الثقافية & \multirow{3}{*}{ طبيعة العمل } \\
\hline$\cdot . r$ & $* 0.7 \varepsilon$ & rV.A. & 1 & rV.A. & خبرة المعلم & \\
\hline$\ldots r$ & $* 0.0$ & rr.vq & 1 & rr.vq & التقاعل & \\
\hline \multirow[t]{3}{*}{$\cdot . r$} & $* 0.07$ & 00.70 & 1 & 00.70 & البيئة الثقافية & \multirow{3}{*}{ يئة العمل } \\
\hline & .1 &. .97 & 1 &. .97 & خبرة المعلم & \\
\hline &.$T_{1}$ & r..v & 1 & $r . . v$ & التقاعل & \\
\hline \multirow[t]{3}{*}{$\cdots \varepsilon$} & $* * 9.1$ & $r \leq .1 \leq$ & 1 & rะ.। & البيئة الثقافية & \multirow{3}{*}{ لعلاقـــــــــــــاء } \\
\hline & T.Y $\varepsilon$ & A. $\leqslant 1$ & 1 & $\wedge .\{1$ & خبرة المعلم & \\
\hline & $\cdot . v V$ &..$Y 7$ & 1 & דצ & التفاعل & \\
\hline
\end{tabular}

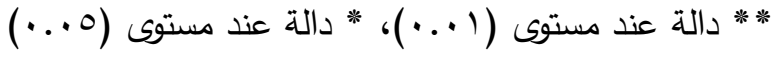

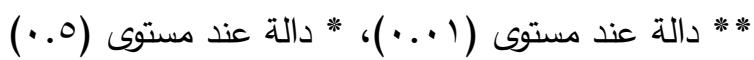


يتضح من جدول (9) وجود فروق دالة إحصائياً في الضـغوط والمهنية لمعلمي التربية

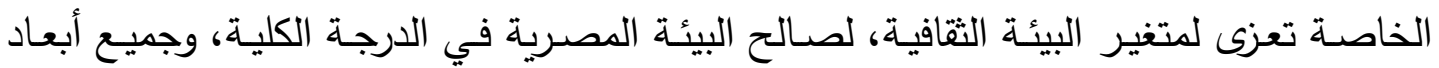

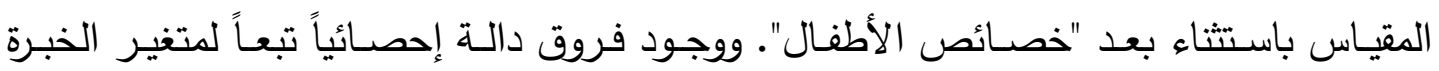

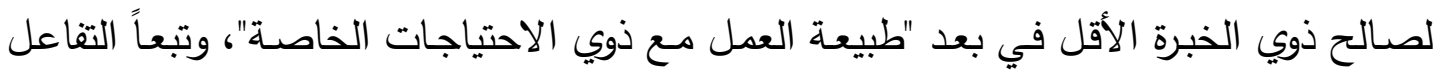
بين المتغيرين لصالح الخبرة الأقل في بعد" طبيعة العمل مع ذوي الاحتياجات الخاصة". وهذه Bush النتيجة في مجملها تحقق صدق الفرض الرابع. وتتقق هذه النتيجة مع نتائج دراسة بوش Antoniou， Polychroni， \& (2010)، ودراسة أنطونيو، وبوليكروني، وفلاتشاكيس

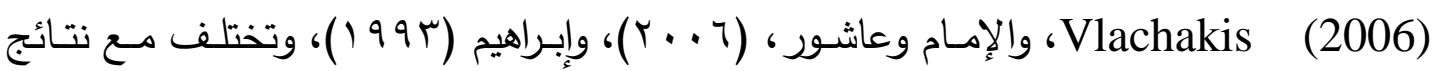

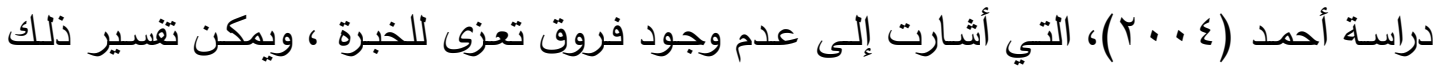

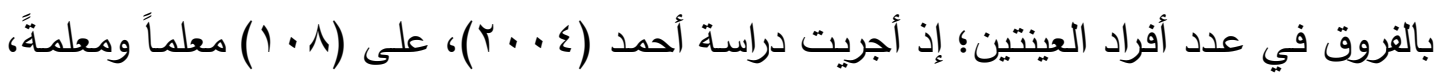

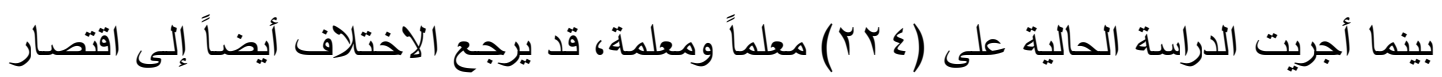

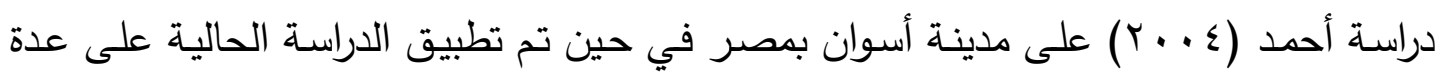

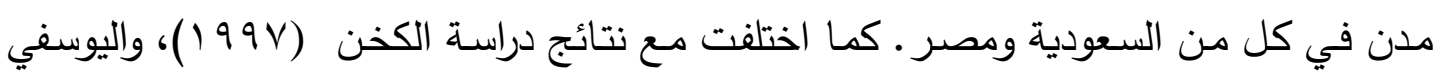
(99 (9.) التي أشارت إلى وجود فروق لصالح ذوي الخبرة الطويلة. وربما يرجع ذلك الاختلاف

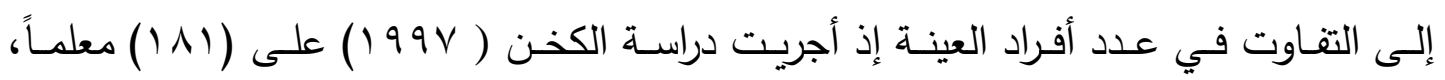

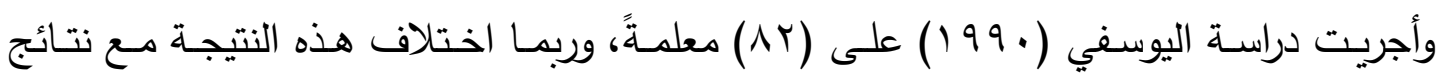
دراسـة اليوسفي (·99 (19) إلى اقتصارها على المعلمات في حين أجريت الدراسة الحالية على معلمين ومعلمات.

$$
\text { توصيـات الدراسـة }
$$

في ضوء ما توصل إليه من نتائج توصي الدراسة الحالية بما يلي: 1- إجراء المزيـــ من الدراسـات عبر الثقافيـة لضــوط معلمي التربيـة الخاصـة في بيئات

$$
\text { عربية جديدة. }
$$

ז- إجراء مزيد من البحوث التي تتـاول المتغيرات التي اختلفت نتائج الدراسـات السـابقة 
ب- إجراء مزيـــ من البحـوث التي تتــاول الضـغوط المهنيـة لمعلمي التربيـة الخاصـة عبر

$$
\text { البيئات العربية. }
$$

ع- إجراء مزيـــ من البحوث التي تركز على البرامج الإرشـادية لتخفيف الضـغوط المهنيـة

$$
\text { لمعلمي التربية الخاصة. }
$$

ه- ضرورة تزويد أقسام التربية الخاصة بنتائج الدراسات المتعلقة بالضغوط المهنية لمعلمي التربية الخاصة لأخذها بعين الاعتبار في مناهج إعداد معلمي التربية الخاصـة؛ بحيث يتم تدريبه على طرق وأساليب مواجهة الضغوط المهنية في بدايتها، ووأدها في مهدها

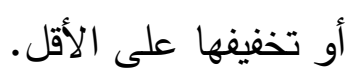

7- حث الإدارات التعليمية على تشجيع المعلمين على التعاون مع الباحثين، وتطبيق أدوات الأبحاث بجدية. والتفكير في حوافز وطرق لتشجيعهم على ذلك بما يضمن تيسير إجراء الأبحاث، ودقة النتائج، ومن ثم تيسير الوصول لأسباب المشكلات وطرق علاجها. 


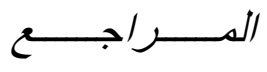

القرآن الكريـ

إبراهيم، شوقية. (س9 9 ( ). الضغوط النفسية للى معلدي التربية الخاصسة ودعلمي التعليم العام.

رسالة دكتوراه، جامعة المنصورة، المنصورة.

إبراهيم، لطفي. (؟9 99 ()). مقياس عمليات تحمل الضنوط. القاهرة: مكتبة الأنجلو المصرية. أبو مصطفى، نظمي عودة، والزين، ديبه موسى. (9 . . (Y). مصادر ضغوط العمل لدى معلمي التربية الخاصـة: دراسة ميدانية على عينـة من معلمي الأطفال المعوقين في مؤسسات التربية الخاصة، بمحافظات غزة. مجلة الجامعة الإسلامية (سلسلة الدراسات الإنسانية)،

$$
. r \leqslant V-r \cdot r \cdot r) i v
$$

أحمـد، محمـد. (ع . . Y). مصـادر الضـغوط لـدى معلمـي التربيـة الخاصــة وعلاقتهـا بـبعض

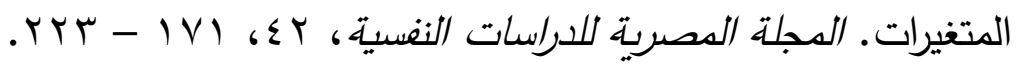

الإمام، محمد، وعاشور ، محمد. (T + . r). الضغوط المهنية وعلاقتها بدافعية التعلم لدى معلمي الطلبة المعاقين سمعياً وبصرياً وعقلياً في الأردن، المجلة العربية للتربية، ،ب (r)، 19

الببلاوي، إيهاب، وأحمد، السيد. (1 . . ب). قضايا معاصرة في التربية الخاصسة. الرياض: دار الزهراء.

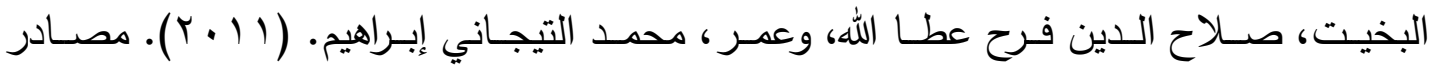
الضـغوط المهنيـة لـدى معلمي ومعلمـات التربيـة الخاصـة وعلاقتهـا ببعض المتغيـرات المهنية والديمغرافية في ولاية الخرطوم. مجلة الجزيرة للعلوم التربوية والإنسانية، ^ ( ( ). بطرس، بطرس حافظ،.(V . . . . . إشاد ذوي الحاجات الخاصة وأسرهم. عمان : دار المسيرة. جبريـل، فـاروق. (1991 ). الضـغوط المهنيـة لـدى المدرسـين ومصــادرها، وعلاقتهـا بـبعض المتغيرات الديموغرافية. مجلة كلية التربية بالمنصورة، 10 (1)، 99 (1) - 1اس. السمادوني، شوقية. (ب9 9 ( ). الضنوط النفسية لدى معلمي ومعلمات التربية الخاصة وعلاقتها بتقدير الذات ـ رسالة ماجستير ، جامعة الزقازيق، الزقازيق. 


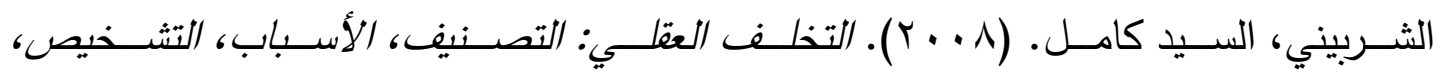
الخصائص. جدة: خوارزم العلمية.

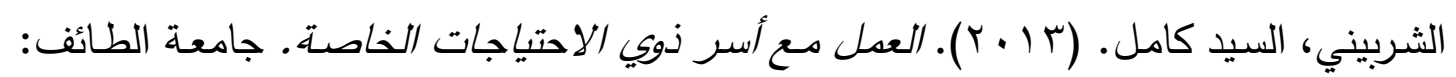
إدارة النشر العلمي.

عبد الحميد، عزت. (799 (199). المساندة الاجتماعية وضغط العدل وعلاقة كل منهها برضـا المعلم عن عمله. رسالة دكتوراه، جامعة الزقازيق، الزقازيق.

عبدالمعطي، حسن مصطفى. ( (999 ) ). ضغوط أحداث الحياة وعلاقتها بالصحة النفسية وبعض

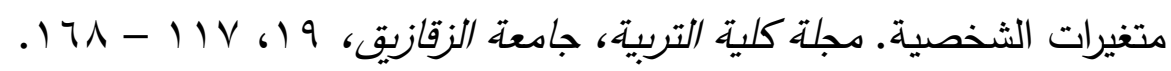
عبدالمعطي، حسـن مصـفىى. (T . . Y). ضـغوط الحياة وأسـاليب مواجهتها. القـاهرة: زهـراء الشرق.

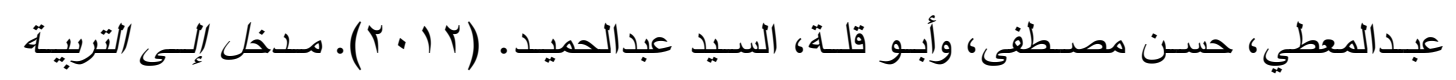
الخاصة. القاهرة: مكتبة زهراء الشرق.

عبدالمعطي، حسن مصطفى، وردادي، زين حسن، وشاش، سهير محمد. (r ( ا ب). سيكولوجية ذوي الاحتياجات الخاصة . القاهرة: مكتبة زهراء الشرق.

عبيد، ماجدة بهاء الدين السيد. (^ . . r). الضغط النفسي ومشكلاته وأثثه على الصحة النفسية. عمان: دار صفاء للنشر والتوزيع. عبيد، ماجدة بهاء الدين السيد. (9 . ؟). تعليم الأطفال المتخلفين عقلياً. عمان: دار صفاء للنشر والتوزيع.

عمارة ، ماجد السيد. (0 . . ب). إعاقة التوحد بين التشخيص والتشخيص الفارق. القاهرة: مكتبة زهراء الثرق.

الكخن، خالد. (99 9 ( ) ) الضغوط المهنية التي تواجه معلمي التربية الخاصسة في الضفة الغربية . رسالة ماجستير • جامعة النجاح الوطنية، نابلس.

المرشدي، طارق منير سعد. (1 . . ب). المشكلات التي تواجه معلمي ذوي صعوبات التعلم في مدارس البنين الابتدائية. رسالة ماجستير ، جامعة أم القرى، مكة المكرمة. 


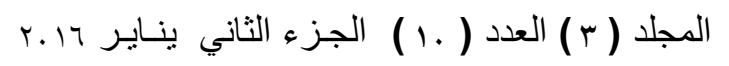

مجلة الـتربيـة الخـاصـة والتـأهيل

مصطفى، أسـامة فـاروق، والثـربيني، السيد كامل. (11 • ب). التوحد (الأسباب، التشخيص،

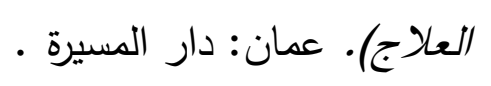

اليوسفي، مشيرة. ( •99 (19). ضـغوط الحيـاة الموجبـة والسـالبة وضـغوط عمل المعلم كمتنبئ

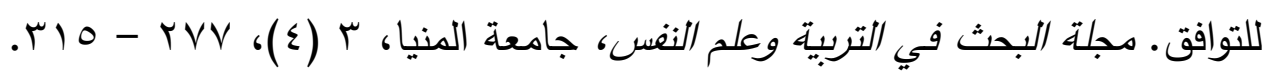

Al-Zboon, E., K., Al_Dababneh, K.A., \& Ahmad, J. (2015). Quality of Worklife: Perceptions of Jordanian Special Education Teachers. Education, 135, (3), 380 - 388.

Antoniou, A. S., Polychroni, F., \& Vlachakis A. N. (2006). Gender and age differences in occupational stress and professional burnout between primary and high-school teachers in Greece. Journal of Managerial Psychology, 21(7), 682.

Brunsting, N. C.,Sreckovic, M. A. \& Lane, K. L. (2014). Special Education Teacher Burnout: A Synthesis of Research from 1979 to 2013. Education and Treatment of Children, 37(4), 681 - 712.

Bush, L. D. (2010). Special Education Teachers and Work Stress: Exploring the Competing Interests Model. Ed.D. Washington State University

Cancio, E. J., Albrecht, S. F., \& Johns, B.H. (2013). Defining Administrative Support and Its Relationship to the Attrition of Teachers of Students with Emotional and Behavioral Disorders. Education and Treatment of Children, 36 (4), 71-94

Dickerson, K. L. (2008). Stress and self-efficacy of special education and general education student teachers during and after the student teaching internship. Texas: A \& M University, ProQuest Dissertations Publishing, 3321680. 
Gersten, R., Keating, T., Yovanoff, P., \& Harniss, M.(2001). Working in Special Education: Factors that Enhance Special Educators Intent to Stay. Exceptional Children, 67(4), 549 - 567.

Green, K. (1994). Careers in Special Education. Occupational Outlook Quarterly, 37 (4), 2.

Hamama, L., Ronen, T. Shachar, K. \& Rosenbaum, M. (2013) Links Between Stress, Positive and Negative Affect, and Life Satisfaction Among Teachers in Special Education Schools. Journal of Happiness Studies, 14 (3), 731-751.

Hatton C., Rivers M., Mason H., Mason L., Emerson E., Kiernan C., Reeves D. \& Alborz A. (1999). Organizational culture and staff outcomes in services for people with intellectual disabilities. Journal of Intellectual Disability Research, 43, 206 - 218.

Khusainova, R. M. (2015). The Influence of the Professional Stress on the Communicative Qualities of Teacher's Personality. Review of European Studies, suppl. Special Issue 7(4), 124-127.

Kodavatiganti, K., \& Bulusu, V. (2011). Stress Indicators and its Impact on Educators: An empirical study of educators working in private educational institutions of Hyderabad, India. SIES Journal of Management, 7(2), 88-96.

Lawson, L. (2011). Burnout and Worklife Perceptions of Special Educators Teaching in a Private School. Walden University, ProQuest Dissertations Publishing, 3479232.

Lazuras , L. (2006). Occupational stress: Negative affectivity and physical health in special and general education in Greece. British Journal Special Education, 33 (4) , 204 - 209. 
Minner, S., \& Lepich, J.(1993). The Occupational Stress of First -Year Urban and Rural Special Educational Teachers. Rural Special Education Quarterly, 12(3), 33-35.

Plash, S. \& Piotrowski, C. (2006). Retention Issues: A Study of Alabama Special Education Teachers. Education, 127(1): 125-128.

Russell, T., \& Wiley, S.(1993). Occupational Stress Levels among Rural Teachers in Areas of Mental Retardation, Learning Disabilities, and Emotional Conflict. Rural Special Education Quarterly, 12(2), $30-40$.

Shyman, E. (2009). Identifying predictors of occupational stress and assessing their relationship to mental health and vitality in special education paraeducators: A correlational study. Teachers College, Columbia University, ProQuest Dissertations Publishing, 3368363.

Behaviour, 6 (1), 44 - 52.

Sutton, G., \& Hubrrty, T.(2001). An Evaluation of Teacher Stress and Job Satisfaction. Education, 105(2), 189 - 192. 